\title{
Exchange Rate Management and Crisis Susceptibility: A Reassessment ${ }^{\dagger}$
}

\author{
Atish R. Ghosh \\ Research Department \\ International Monetary Fund \\ Email: aghosh@imf.org
}

\author{
Jonathan D. Ostry \\ Research Department \\ International Monetary Fund \\ Email: jostry@imf.org
}

\author{
Mahvash S. Qureshi \\ Research Department \\ International Monetary Fund \\ Email: mqureshi@imf.org
}

\begin{abstract}
This paper revisits the bipolar prescription for exchange rate regime choice and asks two questions: are the poles of hard pegs and pure floats still safer than the middle? And where to draw the line between safe floats and risky intermediate regimes? Our findings, based on a sample of 50 EMEs over 1980-2011, show that macroeconomic and financial vulnerabilities are significantly greater under less flexible intermediate regimes — including hard pegs — as compared to floats. While not especially susceptible to banking or currency crises, hard pegs are significantly more prone to growth collapses, suggesting that the security of the hard end of the prescription is largely illusory. Intermediate regimes as a class are the most susceptible to crises, but "managed floats" - a subclass within such regimes-behave much more like pure floats, with significantly lower risks and fewer crises. "Managed floating," however, is a nebulous concept; a characterization of more crisis prone regimes suggests no simple dividing line between safe floats and risky intermediate regimes.
\end{abstract}

JEL Classification Numbers: F31, F33

Keywords: Exchange rate regimes, crisis, vulnerabilities, emerging markets

\footnotetext{
$\dagger$ Paper prepared for the IMF's Annual Research Conference, November 7-8, 2013, Washington DC. We are grateful to Jeffrey Frankel, Pierre-Olivier Gournichas, and participants at the IMF's Annual Research Conference for very helpful comments, and to Hyeon Ji Lee for excellent research assistance. The views expressed herein are those of the authors and do not necessarily represent those of the IMF or IMF policy. ¥Corresponding author. Contact details: International Monetary Fund, HQ1-09-612, $70019^{\text {th }}$ St, NW, Washington DC 20431, USA. Tel: +1 202623 6288; Fax: +1 2025896288.
} 


\section{INTRODUCTION}

"Whatever exchange rate system a country has, it will wish at some times that it had another one."

- Stanley Fischer (1999)

The choice of exchange rate regime is a perennial question facing emerging market economies (EMEs). In a world of increasingly volatile capital flows, even if the ultimate decision depends on a variety of historical, political, and economic factors, any rational calculus on regime choice must take into account its crisis susceptibility. While a voluminous literature on regime vulnerabilities grew out of the EME crises of 1990s and early 2000s, the changing trends in regimes since then (most notably, toward managed floats), the large output drops experienced by EMEs under a variety of regimes during the global financial crisis (GFC), and more recently the impact of "tapering talk" on EME currencies, makes pertinent the question of which regimes are the most vulnerable to crisis, and why.

Conventional wisdom, articulated by Fischer (2001), is the bipolar prescription: countries should adopt floats or hard pegs (monetary union, dollarization, currency board) and avoid intermediate regimes, as they tend to be more susceptible to crisis. While the arguments in favor of free floats are well known, it is less clear why hard pegs - the least flexible regime - should be equally resilient to crisis. Certainly the experience of emerging Europe and some eurozone countries during the GFC suggests that hard pegs may be more prone to growth declines and painful current account reversals, in which case the hard end of the bipolar prescription may be largely illusory.

But the soft end of the prescription is also problematic, a key question there being where to draw the line between floats and more risky intermediate exchange rate regimes. Clearly, occasional interventions during periods of market turbulence or extreme events do not turn a float into an intermediate regime; but how much management of the exchange rate is too much? This is the policy question confronting many EME central banks, an increasing number of which have switched to "managed floats"-i.e., regimes where the central bank does not (at least explicitly) target a particular parity — as they decide in real time how (or whether) to respond to various shocks. Even central banks intending to float freely may find themselves straying toward increasing management of the exchange rate as they react to unfolding events, in turn generating expectations that a de facto intermediate exchange rate regime is in place.

The existing literature provides limited, and generally contradictory, guidance on how much management of the exchange rate is too much. In his seminal work, Fischer $(2001,2008)$ put "managed floats" with free floats - that is, at the safe pole - rather than with the risky intermediate regimes. More generally, for countries with open capital accounts, he considers "a wide range of arrangements running from free floating to a variety of crawling bands with wide ranges" to be appropriate. But most other studies (e.g., Eichengreen, 1994; Obstfeld and Rogoff, 1995; Frankel, 1999; Masson, 2000; Rogoff et al., 2004), adopt a more extreme version of the bipolar view-lumping managed floats (or regimes with wide bands) with 
other intermediate exchange rate regimes. Rogoff et al. (2004), for example, find that managed floats are significantly more prone to financial crisis than free floats, arguing that EMEs would benefit from "learning to float." And in the context of the broad-band regime ( \pm 15 percent around a central rate) adopted by the European Monetary System (EMS) after the crisis of 1992-93, Obstfeld and Rogoff (1995) argue that such systems pose difficulties, and that "there is little, if any, comfortable middle ground between floating rates and the adoption by countries of a common currency."

In this paper, therefore, we examine two related questions: Does the bipolar prescription still hold in the sense that the extremes are safer than the middle? And, at the flexible end, where to draw the line between a safe float and a risky intermediate regime? For our analysis, we go beyond the usual three-way fixed, intermediate and float categorization, and adopt the IMF's detailed de facto classification - which allows us to differentiate among the various intermediate exchange rate regimes - supplementing it with the IMF de jure and Reinhart and Rogoff's (2004) de facto classifications. For each regime, we examine both the underlying vulnerabilities (macro imbalances, financial-stability risks) and the frequency of banking, currency, and sovereign debt crises (following the literature's standard definitions for each of them). Ultimately, however, we are interested in crises because of their impact on welfare, the simplest yardstick of which is output growth. While growth indeed declines sharply during these crises, it is possible that certain regimes are associated with growth collapses that are independent of - or at least not manifested in —one of these crises. To address this possibility, we round out our crisis definitions by adding growth collapses - i.e., sharp decelerations of growth relative to the country's historical norm.

Turning to the line between safe floats and risky intermediate regimes, we find that different regime classifications yield sharply different results for the "managed float" category. We therefore need to go beyond "canned" classifications and instead identify the more crisis prone regimes in terms of their primitive characteristics such as nominal exchange rate flexibility (across various horizons) and degree, direction, and circumstances of foreign currency (FX) intervention. ${ }^{1}$ For this purpose, we adopt an innovative decision-theoretic technique, known as binary recursive tree (BRT) analysis, which allows for arbitrary thresholds and interactive effects among the explanatory variables (e.g., exchange rate flexibility; degree of FX intervention; overvaluation of the real exchange rate, etc.) in determining crisis susceptibility.

Our results, based on a dataset of 50 major EMEs over 1980-2011, may be summarized briefly. First, when it comes to financial vulnerabilities (rapid credit expansion; excessive foreign borrowing; FX-denominated domestic currency lending), and macroeconomic vulnerabilities (currency overvaluation; delayed external adjustment), less flexible intermediate regimes (pegs, bands, and crawls) are significantly more vulnerable than pure

\footnotetext{
${ }^{1}$ While the IMF de facto classification tends to incorporate information on intervention, as discussed below, it involves some subjective judgment. It is also not sufficiently granular in terms of taking into account direction/circumstances of intervention.
} 
floats - but so are hard pegs. Second, intermediate exchange rate regimes as a class are indeed the most susceptible to banking and currency crisis, but de facto managed floats - a subclass within intermediate regimes - behave much more like pure floats, with significantly lower risks and fewer crises. The vulnerabilities under hard pegs however tend to be manifested in growth collapses rather than in banking or currency crises-perhaps because the high cost of exiting the regime makes the authorities reluctant to abandon it, opting instead for long and painful adjustment. Third, at the soft end, we find that there is no simple uni-dimensional dividing line (e.g., according to nominal exchange rate flexibility) between safe floats and risky intermediate regimes. Rather, the key to avoiding crises is to ensure that the real exchange rate does not become overvalued - and what makes for a "safe" managed float is that the central bank intervene in the face of overvaluation pressures and refrain from intervening to defend an overvalued exchange rate.

Our paper contributes to the existing literature in three respects. First, by going beyond existing studies and looking at underlying macroeconomic and financial vulnerabilities, we establish that the hard end of the bipolar spectrum is the most vulnerable - but that these vulnerabilities are manifested mainly in the form of growth crises, implying that the hard end of the bipolar prescription is largely illusory. ${ }^{2}$ Second, by using a finer exchange rate regime classification than the usual three-way categorization, we are able to establish that not all intermediate exchange rate regimes are alike: managed floats (as defined by the IMF's de facto classification) are significantly less susceptible to banking crisis than basket pegs, crawls and bands, or to growth collapses than single currency and basket pegs. Third, by using the BRT analysis to get around the ambiguity across existing regime classifications, we are able to identify the more crisis-prone intermediate regimes according to such characteristics as the degree of nominal exchange rate flexibility and circumstances of FX intervention, which is likely to be more useful for policy purposes than how a canned classification categorizes the regime.

The remainder of this paper is structured as follows. Section II describes the IMF's de facto regime classification used in the analysis, and documents the evolution of exchange rate regimes in EMEs over the past three decades. Section III briefly reviews why certain regimes may be more crisis-prone, and then examines the empirical evidence on their vulnerabilities and susceptibility to banking, currency, sovereign debt, and growth crises. Section IV further explores the characteristics of more crisis-prone intermediate regimes through the use of binary recursive tree analysis. Section V concludes.

\footnotetext{
${ }^{2}$ Some earlier studies have analyzed macroeconomic or financial vulnerabilities associated with different exchange rate regimes individually. E.g., Goldfajn and Valdes (1999) and Ghosh et al. (2010) look at the extent of real exchange rate misalignment under different exchange rate regimes, while more recently, Angkinand and Willett (2011) and Magud et al. (2012) analyze the impact of exchange rate regimes on financial-stability risks.
} 


\section{TRends In EXChange RATE REgIMES IN EMES}

As in any empirical study of exchange rate regimes, our first task is to choose a classification scheme. Early studies (e.g., Ghosh et al., 1995) used de jure classifications - the regime declared by the central bank - but since the bias of these classifications, whereby EME central banks typically claim to follow more flexible exchange rate arrangements than they actually do (characterized as "fear of floating;" Calvo and Reinhart, 2002), has become apparent, subsequent studies generally use de facto classifications (e.g., Ghosh et al., 2003; Reinhart and Rogoff, RR, 2004; Shambaugh, 2004; Levy-Yeyati and Sturzenegger, LYS, 2005). ${ }^{3}$ There is, however, little agreement among the various de facto classifications, and they often produce conflicting results in macroeconomic studies. ${ }^{4}$

Here we mainly use the IMF's de facto classification, which combines statistical methods with qualitative judgment based on IMF country team analysis and consultations with the central bank. ${ }^{5}$ Compared to other de facto classifications, the IMF classification provides wider and more up-to-date coverage (including the period since the GFC), exhibits the greatest consensus across de facto classifications, and makes clearer distinctions between hard pegs and conventional pegs, and between managed floats and pure floats. Moreover, by combining (often confidential) information on the central bank's intervention policy with actual exchange rate volatility, it avoids the occasional anomalies from which purely mechanical algorithm inevitably suffer. ${ }^{6}$

Three phases can be discerned in the evolution of EME exchange rate regimes over the past couple of decades (Figure 1[a]). The 1997-98 Asian crisis, and its immediate aftermath, saw a "hollowing out of the middle" - countries abandoning single currency or other "soft" pegs (mostly in favor of free floats) — consistent with the bipolar prescription. ${ }^{7}$ This trend came to an end around 2004, however, with the proportion of intermediate exchange rate regimes rising in the runup to the GFC, mainly because of the increased adoption of managed floats

\footnotetext{
${ }^{3}$ E.g., in our sample of EMEs (see Appendix A), about 48 percent of de jure pure floats are de facto classified as managed floats, while about 17 percent are de facto classified as other intermediate regimes.

${ }^{4}$ See Frankel et al. (2000), Ghosh et al. (2010), Klein and Shambaugh (2010), and Rose (2011) for a discussion.

5 The IMF's original eight-way de facto classification comprises arrangements with no separate legal tender (monetary union, dollarization), currency boards, conventional pegs (single currency and basket), horizontal bands, crawling pegs, crawling bands, managed floats, and pure floats. The classification categories have been revised slightly since 2008 (see IMF, 2008). For our empirical analysis, we first map the new categories into the old ones to create a consistent series for the full sample period (1980-2011). We then combine the first two categories into hard pegs, combine all crawling arrangements into a single category, and differentiate between single currency and basket pegs - thereby arriving at a seven-way classification.

${ }^{6}$ E.g., the LYS de facto classification includes an "inconclusive" category (where reserves variability is irrelevant for exchange rate movements). Ghosh et al. (2010) show that the IMF's de facto classification is also less idiosyncratic than other classifications in the sense that, observation by observation, it agrees more with the popular de facto classifications (LYS, RR, Shambaugh) than any other individual de facto classification. ${ }^{7}$ Formal statistical tests of the bipolar hypothesis over that period-based on Markov transition matriceshowever, reject it as a positive prediction (see, e.g., Masson, 2001; Bubula and Otker-Robe, 2002).
} 
by EMEs (Figure $1[\mathrm{~b}]$ ). In the third phase, the GFC and beyond, the move toward intermediate exchange rate regimes, especially managed floats, has accelerated markedly. ${ }^{8}$

The intervention patterns underlying the move to greater exchange rate management pre- and post-GFC are, however, quite different. In the runup to the crisis, most EMEs worried that capital inflows would make their exports uncompetitive and therefore sought to limit the appreciation of their currencies. During the crisis, when EMEs were facing a sudden stop or even sharp capital outflows, intervention was to support the currency. Thereafter, the ebbs and flows of capital to these countries have resulted in alternating phases of concern about currency appreciation and depreciation - but in any case, concern about exchange rate volatility, hence the desire to manage exchange rates.

But is this trend of EMEs moving toward managed floats likely to continue? If the bipolar view held as a positive prediction, then Markov transition matrices would imply that hard pegs and free floats would be absorbing states, and together form a closed set. ${ }^{9}$ Estimated transition probabilities for the full sample period (1980-2011) using the three-way classification show that this is not the case: while regimes tend to be highly persistent, none of the off-diagonal probabilities is zero, implying that transitions from every regime to another are possible (Table 1[a]). The floating regime is the least persistent, with many more transitions from floats to intermediate regimes (about 20 percent) than to hard pegs (2 percent). Consistent with earlier findings by Masson (2000) and Bubula and Ötker-Robe (2002), formal tests reject the bipolar view as a positive prediction (Table 1, last row). In fact, according to the steady-state distribution - assuming historical transition probabilities remain unchanged in the future and there are no major shocks to the system-intermediate regimes will be the most prevalent, with about 70 percent of EMEs opting for them in the long-run, and a further 20 percent opting for hard pegs. ${ }^{10}$ Similar results are obtained using a more recent sample (2000-11), except that it is not possible to reject the hypothesis that hard pegs are an absorbing state (though the bipolar prediction itself is strongly rejected). ${ }^{11}$

Turning to transitions among intermediate regimes, Table 2 reports Markov matrices using the finer regime classification. In the full sample, basket pegs are the most persistent regime, followed by crawling pegs/bands, managed floats, and single currency pegs. In the more recent sample, however, while basket pegs remain the most persistent regime, crawls are less

\footnotetext{
8 These broad trends are also apparent using the IMF's de jure and RR's classifications (see Appendix A).

${ }^{9}$ That is, countries would never revert to an intermediate regime from a hard peg or pure float (Masson, 2000).

${ }^{10}$ The long-run (limiting) distribution of regimes is given by $\pi=\lim _{n \rightarrow \infty} \pi_{0} P^{n}$, where $\pi_{\mathrm{o}}$ is some initial distribution of exchange rate regimes, and $P$ is the transition probability matrix.

${ }^{11}$ Despite the somewhat different transition probability matrix obtained from the subsample as compared to the full sample, a formal test of stability of the transition matrix for 2000-11 versus 1980-2011 fails to reject the hypothesis of structural stability (LR test-statistic $=4.18, \mathrm{p}$-value $=0.78$ ). (The test-statistic is given by

$\sum_{i=1}^{m} \sum_{j=1}^{m} \frac{n_{i}\left(P_{i j}-P_{i j}^{0}\right)^{2}}{P_{i j}^{0}}$, where $P_{\mathrm{ij}}$ and $P_{\mathrm{ij}}^{0}$ are the transition probability matrices obtained for the sub and full samples, respectively; and a chi-squared distribution with $m(m-1)$ degrees of freedom.)
} 
persistent, while managed floats and single currency pegs become more persistent. Exits from both hard pegs and floats are much more likely to be toward managed floats in both samples than to any other intermediate regime. The full-sample steady state distribution implies that managed floats would be the most dominant regime in the long-run, with a share of about 31 percent, followed by hard pegs (20 percent), crawling pegs/bands (17 percent), single currency pegs (14 percent) and floats (11 percent). Restricting estimation to the more recent sample suggests and equal split between hard pegs and managed floats of about 30 percent each, followed by single currency pegs ( 15 percent) and pure floats (10 percent). ${ }^{12}$

Overall, these findings strongly reject the bipolar hypothesis as a positive prediction. On the contrary, EMEs seem to favor intermediate exchange rate regimes - and managed floats in particular. Hard pegs may also be more prevalent as several emerging European countries are likely to join the eurozone. Determining the crisis risks of these regimes is therefore a pressing policy question.

\section{EXCHANGE RATE REgIMES AND CRISIS VuLNERABILITY}

Underlying most crises is some form of vulnerability (unsustainable imbalances, excessive balance sheet exposures), and there are several reasons why these vulnerabilities would be worse under less flexible exchange rates regimes than under floats. First, the loss (or limit) of the exchange rate as an adjustment tool makes it more difficult to correct external imbalances, often to the point that the real exchange rate becomes overvalued and large imbalances build up, whose unwinding precipitates a currency crisis (often anticipated by a self-fulfilling speculative attack). ${ }^{13}$ Second, relatedly, regaining competitiveness without nominal exchange rate flexibility puts deflationary pressures on the economy, which in turn may undermine output growth. Third, the exchange rate guarantee implicit in the peg can encourage excessive foreign borrowing by banks (and other domestic entities), especially when there is a favorable interest rate differential for FX borrowing (Rosenberg and Tirpak, 2008; Magud et al., 2011). In turn, open FX limits on banks force them to lend in foreign currency, which is of particular concern when the ultimate borrowers (e.g., households) lack a natural FX hedge. Fourth, to the extent that intervention is not sterilized (e.g. due to the fiscal cost), there may be excessive credit expansion, exacerbated by the implicit exchange rate guarantee that attracts nonresident deposits and expands bank balance sheets (Montiel

\footnotetext{
12 The increase in the steady-state distribution of hard pegs in the 2000-11 sample is a result of both the greater persistence of hard pegs, and a higher transition probability from horizontal bands to hard pegs (the latter reflects Slovakia's entry into the Eurozone). In fact, if the sample is restricted to 2005-11, the probability of exiting hard pegs is zero, and they constitute 100 percent of the regimes in the long-run. Excluding hard pegs from the sample and re-computing transition probabilities for 2005-11, we find that intermediate regimes and floats constitute 95 and 5 percent of the steady-state distribution, respectively.

${ }^{13}$ In a recent paper, Chinn and Wei (2013) find that the nominal exchange rate regime does not matter for external adjustment. Several studies, however, question their results on methodological and definitional grounds, and find that less flexible exchange rate regimes are significantly associated with slower external adjustment (e.g., Hermann, 2009; Ghosh et al., 2013).
} 
and Reinhart, 2001). ${ }^{14}$ Finally, by temporarily suppressing the effects of lax fiscal policy on inflation, less flexible exchange rate regimes may impose less fiscal discipline than flexible regimes (Tornell and Velasco, 2000).

The different types of vulnerabilities may also interact and amplify each other: sharp declines in growth can worsen debt sustainability and impair the quality of bank assets; greater foreign borrowing can lead to large swings of the exchange rate in the event of a sudden stop; but sharp currency movements can strain unhedged domestic balance sheets and result in growth slowdowns. ${ }^{15}$ But even if less flexible exchange rates are likely to be more vulnerable, the form of crisis in which the vulnerability is manifested is likely to depend on the type of exchange rate regime. In particular, the high cost of exiting a hard peg - and therefore the policy discipline and market credibility engendered by the regime - makes currency crises less likely. The same features may also result in smaller fiscal deficits, and therefore, lower risk of debt sustainability problems under hard pegs (though by reducing the scope for inflationary finance, they may make discrete default more likely) than under other less flexible regimes. ${ }^{16}$

By contrast, the very determination of the authorities to maintain the parity means that growth crises are more likely (while the larger imbalances and exposures means that the output cost of any eventual currency crisis will be all the greater-as the collapse of Argentina's currency board amply demonstrated). This suggests that in assessing the resilience of exchange rate regimes, it is important to go beyond the traditional currency and banking crises and also consider other types of crisis such as debt crises and growth collapses. Moreover, since crises are rare events (requiring both an underlying vulnerability and crisis trigger; see Ghosh et al., 2008), and may_-serendipitously — not be realized in the sample, it is important to consider both underlying vulnerabilities and crisis realizations. ${ }^{17}$

\section{A. Financial and Macroeconomic Vulnerabilities}

We begin by examining the relationship between the exchange rate regime and various financial and macroeconomic vulnerabilities by estimating the following model:

\footnotetext{
${ }^{14}$ Backe and Wojcik (2008) highlight another channel through which pegs could fuel domestic credit expansion - for countries with an increasing trend in productivity growth that peg their exchange rate to an advanced economy (with constant productivity growth) currency, the peg may lead to lower interest rates and higher domestic credit compared to a flexible exchange rate regime.

${ }^{15}$ In countries where the banking sector has borrowed heavily from abroad, a banking crisis is often followed by a currency crisis (Kaminsky and Reinhart, 1999).

${ }^{16}$ Frankel et al. (2000) argue that intermediate regimes, mainly basket pegs and bands, inspire less credibility because they are not easily verifiable.

${ }^{17}$ Analyzing vulnerabilities is also useful because crisis observations are coded on the basis of commonly used, yet arbitrary, thresholds of what constitutes a crisis; complementing the analysis with a look at vulnerabilities can therefore yield more robust conclusions. Moreover, identifying vulnerabilities may be a first step to mitigating them, thus making the regime less crisis-prone.
} 
$V_{j t}=x_{j t}^{\prime} \beta_{1}+z_{j t}^{\prime} \gamma_{1}+\eta_{j t}$

where $V_{j t}$ is the financial (rapid credit expansion; excessive foreign borrowing; FXdenominated lending) or macroeconomic (fiscal and current account deficits; real exchange rate overvaluation) vulnerability in country $j$ in time $t ; x$ is a vector of binary variables indicating the IMF's de facto exchange rate regime in place; $z$ includes relevant control variables; and $\eta$ is the random error term. We estimate (1) using Ordinary Least Squares (OLS), and cluster the standard errors at the country level to address the possibility of correlation in the error term. To address potential endogeneity concerns of the exchange rate regime and control variables in (1), we follow existing literature (e.g., Rogoff et al., 2004) and substitute current values of these variables by lagged values. Since exchange rate regimes are slow moving variables, we do not include country-fixed effects, but control for region-specific effects and a range of country characteristics. ${ }^{18}$

\section{Financial vulnerabilities}

Empirical studies generally find that less flexible exchange rate arrangements are more likely to be associated with higher credit to the private sector (Magud et al., 2011) or credit booms (Mendoza and Terrones, 2008; Dell'Ariccia et al., 2012). The same is true in our data set, where change in domestic credit (defined as the 3 -year cumulative change in the ratio of private sector credit-to-GDP) is almost twice as large under hard pegs as under intermediate regimes, and almost four times as large as under floats (Table 3, col. [1]). The aggregate statistic for intermediate regimes, however, masks important differences across them: for instance, change in credit is more than twice as large under basket pegs than under single currency pegs - and almost eight times as large as under managed floats.

More formal analysis confirms these results: the change in credit-to-GDP ratio or credit expansion (i.e., restricting the sample to positive changes in credit-to-GDP ratio) is statistically significantly greater under hard pegs, single currency pegs, basket pegs, or horizontal bands than under pure floats (Table 4, cols. [2], [5]). While the control variables included in the estimation - based on earlier literature (e.g., Mendoza and Terrones, 2008; Magud et al., 2011) — such as real GDP growth, net capital inflows, and foreign borrowing by the banking system are all significant contributors to domestic credit expansion, the association between less flexible exchange rate regimes and private sector credit mostly survives their inclusion in the regression (cols. [3], [6]). Notably, change in credit/credit expansion under other less flexible intermediate regimes (single currency pegs, basket pegs, or horizontal bands) is also statistically significantly higher than under managed floats (as indicated by the test for coefficient equality reported in the last row, Table 4).

\footnotetext{
${ }^{18}$ We exclude off-shore financial centers (such as Panama) from the sample in all estimations. Sample size varies across estimations depending on data availability of different variables. See Appendix B for a description of variables and data sources.
} 
As discussed above, the exchange rate guarantee implicit in a peg (or less flexible arrangements more generally) might also encourage excessive foreign borrowing by the banking system and, given open FX limits, corresponding FX-denominated lending to the private sector. The raw statistics reported in Table 3 (cols. [2]-[3]) suggest that this is indeed the case: both foreign borrowing (measured as foreign liabilities of the banking system, in percent of GDP) and FX-denominated domestic lending (share of domestic FX-denominated loans in total loans of the banking system) are twice as large under hard pegs as under floats, with intermediate exchange rate regimes somewhat closer to the latter.

Regression analysis shows that foreign borrowing by the banking system is significantly greater under less flexible exchange rate regimes than under pure floats; and also under hard and single currency pegs as compared to managed floats (Table 5, col. [2]). These results generally continue to hold for hard pegs and single currency pegs when controlling for other explanatory variables (Table 5, cols. [3]-[6]). Hard pegs and basket pegs are also associated with a significantly greater proportion of FX-denominated lending in total bank lending as compared to free floats (Table 6, col. [2]), though the results weaken when we control for net capital flows and bank foreign liabilities, which suggests that less flexible regimes induce greater FX-denominated lending by encouraging funds from abroad (cols. [3]-[6]). ${ }^{19}$

The regressions reported in Tables 5 and 6 also point to policy measures that can help reduce these risks. For instance, consistent with the findings of Ostry et al. (2012), controls on capital inflows are associated with significantly lower banking system external liabilities (Table 5, col. [4]) and, more surprisingly, with a lower proportion of FX-denominated domestic bank lending (Table 6, col. [4]). ${ }^{20}$ Likewise, restrictions on FX-denominated lending naturally reduce the proportion of such loans in total bank lending (Rosenberg and Tirpak, 2008; Ostry et al. 2012), while open FX-limits have a stronger impact on foreign borrowing by the banking system (Tables 5 and 6, cols. [5]-[6]).

\section{Macroeconomic vulnerabilities}

Beyond financial vulnerabilities, less flexible exchange rate regimes may be associated with greater macroeconomic vulnerabilities: fiscal deficits, current account deficits, and real exchange rate overvaluation. What is the formal empirical evidence? Fiscal deficits are lower under hard pegs than under most other less flexible exchange rate regimes - with the exception of basket pegs (Table 3, col. [4])_-but the differences are not statistically significant from free floats (again, except for basket pegs, which have significantly higher fiscal balances than free floats; Table 7, cols. [2]-[3]). Both hard pegs and intermediate regimes are associated with significantly greater overvaluation of the real exchange rate (measured simply as the deviation of real effective exchange rate from trend) than pure

\footnotetext{
${ }^{19}$ Dollarized economies are excluded from the sample when computing the share of FX-denominated loans in total bank lending since, by the very nature of the regime, all loans would be classified as FX-denominated.

${ }^{20}$ Ostry et al. (2012) explain this result by noting that inflow controls on the banking system will imply fewer FX-liabilities and hence, given open FX-limits, less FX-denominated lending.
} 
floats - and this holds regardless of controlling for capital inflows (which is itself significantly associated with overvaluation). The fine classification, however, shows that it is hard pegs and single currency, basket, and crawling pegs that are susceptible to (statistically significant) overvaluation: managed floats do not exhibit greater overvaluation than pure floats (Table 7, cols. [4]-[6]).

Less flexible exchange rate regimes do appear to impede external adjustment—on average, current account imbalances tend to be larger under hard pegs and intermediate regimes than under floats (Figure 2). Prior to reversals - defined as large reductions in the current account imbalances - surpluses and deficits also tend to be larger under these regimes relative to pure floats (Table 8, cols. [1]-[3]). While nothing forces adjustment on surplus countries, deficit countries can lose financing abruptly especially when large imbalances have built up. Accordingly, the (unconditional) reversal probability is significantly greater for hard pegs and (almost) all intermediate exchange rate regimes (col. [4]).

\section{B. Crisis Propensity}

The findings above suggest that less flexible exchange rate regimes may be much more vulnerable to crisis. But do these vulnerabilities translate into actual crises? And are all less flexible regimes equally prone to different types of crisis? In this section, we empirically explore these questions with regard to banking, currency, and sovereign debt crises, as well as general growth collapses, by estimating models of the following form:

$$
\operatorname{Pr}\left(\text { Crisis }_{j t}=1\right)=F\left(x_{j t}^{\prime} \beta_{2}+z_{j t}^{\prime} \gamma_{2}\right)
$$

where Crisis $_{j t}$ is an indicator variable of whether a crisis (banking, currency, debt, or growth) occurs in country $j$ in period $t ; x$ indicates the exchange rate regime in place (before the onset of the crisis), and $z$ includes various relevant control variables (lagged). We estimate (2) using the probit model, and as before, include region-specific effects, and cluster the standard errors at the country level.

To define the various types of crisis, we follow the existing literature. Systemic banking crises are those where there are significant signs of financial distress in the banking system, requiring significant policy intervention methods in response to significant losses (Laeven and Valencia, 2012). Currency crises are depreciations of the nominal exchange rate against the US dollar of at least 30 percent that is also at least 10 percentage points greater than the depreciation in the previous year (Frankel and Rose, 1996). External debt crises are identified as events of sovereign debt default and/or restructuring. ${ }^{21}$ Growth collapses are defined as those that are in the bottom fifth percentile of growth declines (current year relative to the average of the three previous years), and correspond to a fall in the growth rate of real GDP of about 7.5 percentage points.

${ }^{21}$ Our source for all three types of crisis (banking, currency and debt) is Laeven and Valencia (2012). 
An initial snapshot shows that currency and banking crises are the most common form of financial crisis in EMEs, while sovereign debt crises the least common (Table 9). Large growth declines are also quite common, and not all of them are accompanied by another type of crisis. For example, only about one-third of growth collapses occur with or within three years of a banking or currency crisis (and fewer than 10 percent occur in the context of a debt crisis). Banking crises seem to be drivers of currency and debt crises - around one-half of which occur within three years of a banking crisis, whereas some 15-30 percent of banking crises happen within three years of a debt or currency crisis.

\section{Banking and currency crises}

A number of studies have documented the higher propensity of banking (Domaç and Peria; 2003; Ghosh et al., 2003; Rogoff et al., 2004; Angkinand and Willett, 2011) and currency (Bubula and Ötker-Robe, 2003; Ghosh et al., 2003; Rogoff et al., 2004) crises in countries with less flexible exchange rate regimes. Our own empirics (Table 3, col. [6]) suggest that less flexible exchange rate arrangements are indeed associated with more banking crises, but that the relationship is not monotonic. Intermediate exchange rate regimes are about twice as likely to experience a banking crisis as a hard peg and about four times as likely as a float. Delving deeper into the intermediate regimes, it is crawling arrangements and horizontal bands that are the most crisis-prone (with about 7 percent of them experiencing a banking crisis), followed by basket pegs; while managed floats are the least likely to experience a banking crisis - and no more likely than pure floats.

Results from the probit model confirm these casual observations and show that intermediate exchange rate regimes are statistically significantly more likely to experience banking crises than pure floats (Table 10, col. [1]). Among intermediate regimes, it is basket pegs, horizontal bands, and crawling pegs that have a significantly greater propensity to banking crises; the coefficients on single currency pegs and managed floats are statistically insignificant (col. [2]).

If we add other variables that have been identified as important determinants of banking crisis in earlier literature (e.g., Demirgüç-Kunt and Detragiache, 1998; Angkinand and Willet, 2011) such as real exchange rate overvaluation, banking system foreign liabilities, domestic credit expansion, and net capital flows (in percent of GDP), we find the estimated coefficients of these variables to be statistically significant and of the expected signs. Thus, an increase in overvaluation, faster domestic credit expansion, excessive foreign borrowing, and larger inflows are associated with a higher banking crisis probability. Since these variables may themselves be influenced by the regime (Tables 4-7), the addition of these explanatory variables can have three possible effects on the magnitude of the estimated coefficients of the regime variables in (2): leave them unchanged, decrease them, or increase them. To the extent that the regime coefficients remain unchanged, it means that the greater crisis propensity of some regimes is unrelated to these risks. If the coefficient declines ( $a$ fortiori, becomes insignificant), then the crisis susceptibility of the regime is through these 
channels only (if it turns negative, then the regime is less susceptible to crisis than would be expected on the basis of how it scores on these vulnerabilities); and if it increases, then the regime is more susceptible to crisis than its risks would imply.

The estimated coefficients on basket pegs, horizontal bands, and crawling pegs diminish in magnitude, and become statistically insignificant in the case of basket pegs, with the inclusion of the additional variables (Table 10, col. [3]). The result is not surprising since, as discussed above, these regimes tend to have the largest financial-stability and macroeconomic vulnerabilities; controlling for them, the regimes become less important. More surprising is that hard pegs score significantly worse on most of these risks (Table 3, cols. [1]-[5]), yet suffer fewer banking crises. One reason may be that, knowing the strictures imposed by the hard peg, including on LOLR operations (Angkinand and Willet, 2011), banking supervision is tighter, and other compensatory mechanisms are built into the design of the regime. ${ }^{22}$ Another reason may be that around one-third of banking crises are preceded by currency crises (Table 9) and, hard pegs tend to have fewer of these, as shown in Table 3.

Looking at currency crisis, these are almost five times as likely under an intermediate regime than under a hard peg, and twice as likely as under a pure float (Table 3, col. [7]) - though the differences are not statistically significant (Table 10, col. [5]). Within intermediate exchange rate regimes, only crawling pegs exhibit a statistically significantly higher frequency of crisis than pure floats (col. [6]). Controlling for real exchange rate overvaluation, banking system foreign liabilities, the current account balance, and foreign exchange reserves (all of which are statistically significant with the expected signs), the coefficient on crawling pegs becomes insignificant, while the coefficient on hard pegs becomes negative and statistically significant at the 10 percent level (col. [6]). In other words, hard pegs have fewer currency crises than would be expected given their macroeconomic and financial vulnerabilities. Presumably, the greater policy discipline imposed by the hard peg together with the reluctance of speculators to take on a central bank committed to defending the parity, enables hard pegs to handle these risks without experiencing a currency crisis.

\section{Sovereign debt crises and growth collapses}

Unconditionally, the likelihood of a sovereign debt crisis is the same under hard pegs and intermediate exchange rate regimes ( 2 percent of the observations) - and around four times as large as under a pure float (Table 3, col. [8]). Among the intermediate exchange rate regimes, single currency and crawling pegs exhibit the highest crisis probability, roughly twice that under managed floats. None of these differences are statistically significant, however, regardless of whether other control variables (real exchange rate overvaluation,

\footnotetext{
${ }^{22}$ E.g., Bulgaria's currency board arrangement incorporates a pre-funded "banking department" as a precaution against banking crises.
} 
reserves, fiscal balance, real GDP growth, inflation - each of which is statistically significant with the expected sign) are included in the probit (Table 11, cols. [1]-[3]).

Ultimately, we are interested in crises that matter - the simplest yardstick of which is whether output growth suffers. On average, during banking, debt, or currency crises, growth slows by some $2 \frac{1}{2}$ to 4 percentage points (comparing the year of the crisis to the previous three years). ${ }^{23}$ But obviously not all these crises have an appreciable impact on growth, and at the same time, there may be other types of crisis that negatively affect growth but that are not covered here. This suggests that it may be interesting to see whether general growth collapses, controlling for exogenous and external shocks, vary by regime.

Unconditionally, such growth collapses are far more common under hard pegs than under either intermediate or floating regimes, with more than 10 percent of hard pegs experiencing a sharp decline in real GDP growth (Table 3, col. [9]). The aggregate classification confirms that hard pegs are significantly more prone to growth collapses than pure floats, while the finer classification shows that hard, single currency, and basket pegs are all more prone to such crises than managed or pure floats (Table 11, cols. [4]-[5]). The association between these regimes and growth crises holds controlling for other explanatory variables such as growth in major trading partners, the current account balance, and the stock of reserves - all of which are statistically significant with the expected signs (Table 11, col. [6]).

The results also hold controlling for banking, currency, or debt crises (col. [6]). Why might the less flexible exchange rate arrangements be associated with growth collapses beyond the effects of other crises? One reason is the loss of the nominal exchange rate as an adjustment mechanism. For instance, a sharp curtailment of foreign financing (even if it does not result in a currency crisis) will require a larger decline in activity and output to elicit a given improvement in the current account when the exchange rate cannot adjust. This is certainly the story behind some of the growth collapses in the pegged exchange rate regime sample (e.g., Argentina in 2000s, and Estonia and Latvia in the GFC).

\section{Sensitivity Analysis}

To check the robustness of our estimates reported above, we conduct a range of sensitivity tests with alternate specifications and different exchange rate regime classifications, and discuss relevant endogeneity issues.

\section{Alternate specifications}

The results reported in Tables 10 and 11 consider the different types of crisis individually, but if all these crises are pooled together, we find that almost all types of less flexible exchange rate regimes, except for managed floats (and basket pegs), are significantly more

\footnotetext{
${ }^{23}$ Restricting sample to crises associated with at least a slowdown in real GDP growth yields similar results.
} 
susceptible to crisis than pure floats (Table B2, col. [1]). This result holds regardless of whether other control variables (including macroeconomic and financial vulnerabilities) are added to the model or not (col. [2]). The results are generally also robust to the inclusion of additional control variables (that may be correlated both with regime choice as well as crisis susceptibility) such as trade openness, institutional quality, capital account openness index, crisis contagion variables, year effects, and to using different proxies for bank foreign borrowing (such as bank net foreign assets to GDP ratio; cols. [3]-[7], [10]-[14]). In the case of currency crisis, controlling for hyper inflation (annual inflation rate $\geq 40$ percent; col. [8]), or adding the lagged banking crisis variable also does not change the results significantly (though, as in Kaminsky and Reinhart (1999), we find that banking crisis significantly raise the likelihood of a currency crisis by about 6 percentage points; col. [9]).

\section{Endogeneity}

One concern with any study of performance under alternative exchange rate regimes is the possibility of regime endogeneity or reverse causality. Following earlier literature, e.g., Reinhart et al. (2004), we always use the one year lag of the regime classification to capture the regime that was in place at the time of the crisis, thereby mitigating endogeneity concerns (and since regimes tend to be persistent while crises are discrete and rare events, endogeneity concerns are anyway less likely to be pertinent here than for some other studies such as the link between fixed exchange rates and low inflation). For reverse causality to be driving our finding that less flexible regimes are more crisis prone would then require that countries switch toward less flexible regimes in the runup to a crisis (or more generally, as they become more vulnerable to crisis). ${ }^{24}$ But empirically, that is not the case. In less than a quarter of the crisis cases in our sample does the de facto regime switch between years $t-2$ and $t-1$, and of these switches, there is an almost equal split between moves toward less flexibility and moves toward greater flexibility.

More generally, not only is it difficult to establish a link between (subsequent) crises and regime switches, it is also difficult to find evidence that underlying macroeconomic and financial vulnerabilities prompt switches in the exchange rate regime. For example, Table B3 shows that there is no statistically significant difference in the current account balance (to GDP), net financial flows (to GDP), credit expansion, FX-denominated domestic lending, or bank foreign borrowing between exchange rate regime switches toward greater flexibility and regime switches away from flexibility. Real exchange rate overvaluation is the only variable for which we find the difference to be statistically significant - countries with more overvalued exchange rates opt for more flexible regimes. ${ }^{25}$ These observations are consistent

\footnotetext{
${ }^{24}$ Conversely, if there is endogeneity such that countries opt for greater flexibility in anticipation of the crisis, it would tend to downward bias the coefficients on less flexible exchange rate regimes. In this respect, since we mostly find a statistically significant effect of less flexible exchange rate regimes on crisis probability, our estimates could be treated as presenting a lower bound.

${ }^{25}$ This strengthens our results since the finding of an association between less flexible regimes and vulnerabilities is then despite, not because of, potential endogeneity. The statistical significance of the coefficient however disappears once we exclude crisis observations from the regime switches.
} 
with earlier studies (e.g., Rogoff et al., 2004; Klein and Shambaugh, 2010), who are unable to find robust (observed) predictors of exchange rate regime choice. As such, it appears implausible for reverse causality to be driving our results. ${ }^{26}$

\section{Other classifications}

The overall picture that emerges from the results obtained above is that managed floats are no more prone to crisis than pure floats, and significantly less so than other less flexible exchange rate regimes. Despite greater macroeconomic and financial vulnerabilities, hard pegs are as prone to financial crisis as pure floats, although they are significantly more prone to growth crises than either pure or managed floats. In broad brush terms, a similar picture is obtained using alternative regime classifications, though there are some differences. Using the de jure classification, for example, the main difference is that managed floats rather than crawling pegs have a statistically significantly higher probability of banking crises (Table B4, cols. [2]-[3]); this result is likely the outcome of a large proportion of de jure "managed floats" being in fact a tightly managed regime that are de facto identified as crawling arrangements. Other results - specifically, that hard pegs have fewer currency crises and more growth collapses; and that managed floats are no more prone to currency and debt crises, or growth collapses than pure floats - carry through (cols. [4]-[12]).

As for RR's de facto classification, their category of "collapsing currencies" corresponds almost exactly to currency crisis observations, so it is not meaningful to examine whether their other regimes are associated with currency crises (all the coefficients are statistically insignificant; Table B5). On growth crises, as with the IMF classification, hard pegs come out to be significantly more prone to growth collapses than pure floats (cols. [11]-[12]). The key difference between earlier results and those with RR's classification is again for the managed float category, where using the latter, there is a significantly positive association between these regimes and debt and banking crises. This is consistent with the finding of Rogoff et al. (2004) who, using RR's classification, also find that banking crisis are more likely under managed floats than free floats.

Thus, while our findings on hard pegs and most other intermediate regimes are robust to the use of alternative classifications, the robustness of the results across regimes appears to break down at the flexible end of the spectrum, notably for the "managed float" category. Using the IMF de facto classification, managed floats are no more prone to crisis than pure floats; using the IMF's de jure or the RR's de facto classifications, they are closer to other intermediate regimes in terms of crisis susceptibility. We attempt to address this issue rigorously below.

\footnotetext{
${ }^{26}$ As Rogoff et al. (2004) note "This problem [endogeneity] cannot be fully resolved but is mitigated by the relatively long duration of the typical regime under the Natural [i.e., de facto] classification, implying that temporary changes in performance do not influence the choice of regime. The problem is also mitigated by using as an explanatory variable the regime prevailing in the previous one or two years...."
} 


\section{Where TO DRAW THE LiNe?}

The finding that the RR managed floats are almost as risky as other intermediate regimes, whereas managed floats as defined by the IMF classification are almost as safe as pure floats, implies that different classifications are capturing different regimes under the rubric of managed floating - an admittedly nebulous category. That the IMF's de facto managed float category captures the contours that define a relatively safe regime begs the question of what really constitutes "safe" managed floating - something that presumably Fischer (2001) had in mind when describing the floating pole as constituting "a managed float with no specified central rate, or as independently floating."

Like the IMF's de facto classification, RR's managed float category explicitly excludes regimes targeting a specific exchange rate parity, while in terms of nominal exchange rate volatility (short- and long-run) the relative ranking of regimes also looks similar (Figure B1). So where does the difference lie? To address this question, we need to go beyond canned classifications and instead characterize the more risky intermediate regimes along various relevant dimensions (e.g., exchange rate flexibility; degree of FX intervention; overvaluation of the real exchange rate; financial-stability risks, etc.). To this end, we use an innovative decision-theoretic technique, known as binary recursive tree (BRT) analysis that allows for arbitrary thresholds and interactive effects among the explanatory variables. Since the ambiguity pertains to intermediate regimes, in what follows we exclude observations that are coded as hard pegs or pure floats under both the IMF and RR classifications.

Formally, a binary recursive tree is a sequence of rules for predicting a binary variable, $y$, (i.e., crisis vs. noncrisis) on the basis of a vector of explanatory variables, $x_{j}$, where $j=1 \ldots J$, such that at each level, the sample is split into two sub-branches according to some threshold value of one of the explanatory variables, $\hat{x}_{j}$. The threshold value $\hat{x}_{j}$ is chosen as the value that best discriminates between crisis and noncrisis observations based on a specific criterion. ${ }^{27}$ The splitting is repeated along the various sub-branches until a terminal node is reached. This technique thus establishes a hierarchy among variables such that an explanatory variable that appears toward the top of the tree may be considered more important in distinguishing between the crisis and noncrisis cases than one appearing on a lower sub-branch. For example, if the main characteristic that mattered for crisis susceptibility was exchange rate flexibility, then the tree would split on some threshold value of flexibility, and could further split based on this or some other variable.

In our application, the dependent variable is 1 if the country experiences a banking or currency crisis and 0 otherwise, and the candidate variables are the vulnerability indicators used above (credit expansion, real exchange rate overvaluation, banking system foreign

\footnotetext{
${ }^{27}$ While several algorithms are available to search for the best split (e.g., minimizing the sum of type I and type II errors) we employ the Improved Chi-squared Automatic Interaction Detector (CHAID), which uses a chisquared test to determine the best split (Kass, 1980 provides the details). Implementation of CHAID is undertaken using the SIPINA classification tree software.
} 
liabilities, share of FX credit) together with flexibility of the nominal exchange rate and degree of intervention as characteristics of the exchange rate regime, and both the IMF de facto and RR regime classifications. ${ }^{28}$

Figure 3 presents the resulting binary recursive tree, with conditional probabilities of a crisis indicated at each node. ${ }^{29}$ The first variable used for splitting the sample turns out to be real exchange rate overvaluation at the threshold value of 5 percent: the conditional probability of a crisis in countries with real exchange rate overvaluation greater than this threshold (the right branch of the tree) is 30 percent, whereas that for countries with overvaluation below this threshold is only 4 percent. Continuing along the right branch, the second node depends on credit expansion such that countries with a 3-year cumulative change in domestic credit to GDP ratio in excess of 30 percentage points are more than thrice as likely to have a crisis than those without such a credit boom. Further down the branch, it is overvaluation that matters again, with countries whose currencies are more than 12 percent overvalued having a 55 percent conditional probability of crisis compared to 20 percent for countries whose currencies are not as overvalued. Of the highly overvalued countries (overvaluation in excess of 12 percent), however, those that intervene heavily are much more likely to experience a crisis than those that do not; while when overvaluation is below the 12 percent threshold, it is nominal exchange rate flexibility that matters, with countries that have less flexible exchange rates almost four times as likely to experience a crisis than those with more flexible exchange rates. Note that nothing prevents the algorithm from further splitting the tree (using any of the regressors); however, given the stopping rule for the algorithm, the improvement in the fit is not sufficient to justify the additional complexity of the tree.

Moving on to the left branch of the tree (i.e., countries whose real exchange rates are less overvalued than 5 percent), we see that it is also credit expansion that matters - countries with a 3-year cumulative change in domestic credit to GDP ratio in excess of about 32 percentage points are much (i.e., 15 times) more likely to have a crisis than those without such a boom. Continuing down the branch of countries with relatively less credit expansion, it is countries with more flexible exchange rates with a higher likelihood to experience a crisis. The final node makes clear why: of these countries with more flexible exchange rates, those that are more overvalued are 6 times more likely to experience a crisis than those without overvalued currencies.

\footnotetext{
${ }^{28}$ Intervention is defined as $I=|\Delta R| /(|\Delta R|+|\Delta E|)$ where $\Delta R$ is the annual percentage change in reserves (where change in reserves is measured as reserve flows from the Balance of Payments, rather than change in the stock of reserves, to avoid valuation changes), and $\Delta E$ is the annual percentage change in the nominal effective exchange rate (NEER). Results remain essentially similar if the nominal exchange rate against the major anchor currency (such as the US dollar or euro) is used instead. I ranges from zero (no intervention; free float) to one (full intervention; fixed exchange rate). Exchange rate flexibility is defined in terms of monthly NEER volatility-i.e., rolling standard deviation of monthly percentage changes in the NEER over 6, 12 or 36 months. ${ }^{29}$ All variables used for classification are lagged one period. The tree correctly classifies about 94 percent of the sample; 29 and 99 percent of the crisis and noncrisis observations, respectively.
} 
It is noteworthy that neither the IMF nor the RR classifications appears anywhere in the tree; that is, the other explanatory variables (including exchange rate flexibility and intervention) are better at discriminating between crisis and noncrisis cases. The BRT analysis thus makes clear that there is no simple dividing line (e.g., according to nominal exchange rate flexibility) between "safe" and "risky" intermediate exchange rate regimes. Rather, what determines whether the regime is safe or risky is a complex confluence of factors, including exchange rate flexibility, degree of intervention, and, of course, economic and financial vulnerabilities - of which real overvaluation features as the most important variable. The only way to make the regime classifications enter the tree is to drop the overvaluation, intervention, and exchange rate flexibility variables. With this more restricted set of explanatory variables, the IMF classification does enter the tree at the second branch, with a threshold at the managed float category such that countries with pure or managed floats have a conditional probability of crisis of 4 percent, compared to 9 percent for countries that have less flexible regimes. ${ }^{30}$ Thus, while the IMF de facto classification does enter the tree, it is not particularly very good at discriminating between crisis and noncrisis cases. As for the RR classification, even with the restricted set of explanatory variables, it does not enter the tree at all, and is unsuccessful in discriminating between safe and risky intermediate regimes.

To delve deeper into how exchange rate overvaluation, flexibility and intervention interact, we restrict the sample to observations where the real exchange rate is overvalued by at least 5 percent (the threshold of the first node), and refine the intervention variable to capture (i) cases where the central bank is buying FX, thus helping to prevent (further) overvaluation; (ii) cases where the central bank is selling FX, thus defending (an overvalued) exchange rate (these may not be perfect complements because there could be cases where the central bank is not intervening in either direction).

Figures 4 and 5 plot the resulting binary recursive trees using the two intervention variables, respectively. Again, the first node of the tree splits according to overvaluation of the exchange rate: countries whose currencies are more than 12 percent overvalued have a conditional probability of crisis of 55 percent compared to 23 percent for countries with currencies less overvalued than 12 percent. The further nodes split according to exchange rate flexibility and intervention. Countries where intervention is against the wind - that is, central banks buy FX in the face of overvaluation-have a conditional probability of crisis of only 4 percent compared to 24 percent for countries where the central bank is not intervening against the wind (Figure 4). Conversely, when the central bank sells FX (i.e., seeks to defend) an overvalued currency, the conditional probability of crisis is 83 percent compared to 44 percent when it does not (Figure 5).

In other words, it is not intervention per se that makes the regime risky. On the contrary, intervention to prevent (further) overvaluation can reduce the risk of crisis, while intervention to defend an overvalued exchange rate makes the regime more crisis prone.

\footnotetext{
${ }^{30}$ This tree is not reported here for brevity but is available upon request.
} 
These results help explain why managed floats under the IMF classification are relatively safer than the managed floats as defined by the RR classification. First, about 40 percent of the cases where the real exchange rate is overvalued are classified as managed floats by RR, compared to 25 percent under the IMF's de facto classification. Second, 26 percent of the cases where the central bank is defending an overvalued exchange rate are classified as managed floats by RR, compared to 20 percent under the IMF's de facto classification. The IMF de facto classification thus better captures the safer management of the exchange rate, but still cannot fully capture it since there is no simple dividing line between the characteristics that are relevant for crisis propensity.

\section{Conclusion}

Writing in the aftermath of the Asian crisis, Fischer (2001) gave a bipolar prescription for regime choice, whereby EMEs should adopt floats or hard pegs, but avoid intermediate regimes as they are more prone to crisis. In this paper, we draw on a large sample of EMEs over the period 1980-2011 to examine whether this prescription has an empirical basis. Consistent with the bipolar prescription, we find that free floats are indeed the least vulnerable to crisis. At the other end of the spectrum, however, we find that hard pegs exhibit some of the greatest vulnerabilities in terms of external imbalances, real exchange rate overvaluation, banking system's foreign liabilities, domestic credit expansion, and FXdenominated domestic lending. Given the high costs of exiting hard pegs, and the central bank's corresponding reluctance to abandon the regime, these vulnerabilities typically do not translate into banking or currency crises, but they do imply that hard pegs are significantly more susceptible to growth crises. The security of the hard end of the bipolar prescription thus turns out to be largely illusory.

Ambiguous in the bipolar prescription is where to place managed floats. While Fischer placed them at the safe pole with free floats, others would place them in the risky intermediate regime category. Empirically, different classifications give starkly different answers, which is especially problematic as managed floats are becoming increasingly popular among EMEs. Using binary recursive tree analysis, we establish that there is no simple dividing line - for instance, according to exchange rate flexibility-between safe and risky managed floats. Rather, what distinguishes safe from risky management of the exchange rate is whether the central bank intervenes to limit overvaluation, and refrains from intervening to defend an overvalued exchange rate.

While this insight is probably more useful for policy purposes than canned regime classifications, there remain numerous challenges for central banks opting for managed floats. In particular, they need to assess, in real time, whether capital flows are likely to be temporary or persistent, and accordingly, whether the exchange rate is becoming overvalued relative to its equilibrium value. What this paper has shown is that managed floats can be a relatively resilient regime, but more research is necessary to define more completely the contours of safe managed floats. 


\section{REFERENCES}

Anderson, H., 2008, "Exchange Policies before Widespread Floating (1945-89)," mimeo (Washington DC: International Monetary Fund).

Angkinand, A., and T. Willett, 2011, "Exchange Rate Regimes and Banking Crises: The Channels of Influence Investigated," International Journal of Finance and Economics, 16(3), pp. 256-274.

Backe, P. and C. Wojcik, 2008, "Credit Booms, Monetary Integration, and the Neoclassical Synthesis," Journal of Banking and Finance, 32(3), pp. 458-470.

Bubula, A., and I. Ötker, 2002, "The Evolution of Exchange Rate Regimes since 1990: Evidence from De Facto Policies?" IMF Working Paper WP/02/155 (Washington DC: IMF).

Bubula, A., and I. Ötker, 2003, “Are Pegged and Intermediate Regimes More Crisis-prone?" IMF Working Paper WP/03/223 (Washington DC: International Monetary Fund).

Calvo, G., and C. Reinhart, 2002, "Fear of Floating," Quarterly Journal of Economics, 117(2), pp. 379-408.

Chinn, M., and S.-J. Wei, 2013, “A Faith-based Initiative Meets the Evidence: Does a Flexible Exchange Rate Regime Really Facilitate Current Account Adjustment?" Review of Economics and Statistics, 95(1), 168-184.

Dell'Ariccia, G., D. Igan, L. Laeven, H. Tong, B. Bakker, and J. Vandenbussche, 2012, "Policies for Macrofinancial Stability: How to Deal with Credit Booms," IMF Staff Discussion Note SDN/12/06 (Washington DC: International Monetary Fund).

Demirgüç-Kunt, A., and E. Detragiache,1998, "The Determinants of Banking Crises in Developing and Developed Countries," IMF Staff Papers, 45(1), pp. 81-109.

Domaç, I., and M. Peria, 2003, "Banking Crises and Exchange Rate Regimes: Is There a Link?” Journal of International Economics, 61(1), pp. 41-72.

Eichengreen, B., 1994, International Monetary Arrangements for the $21^{\text {st }}$ Century (Washington, DC: Brookings Institution).

Fischer, S., 1999, "The Financial Crisis in Emerging Markets: Some Lessons." Speech delivered at the conference of the Economic Strategy Institute, Washington DC (available online at: http://www.imf.org/external/np/speeches/1999/042899.htm\#1). , 2001, "Exchange Rate Regimes: Is the Bipolar View Correct?" Journal of Economic Perspectives, 15(2), 3-24. 
, 2008, "Mundell-Fleming Lecture: Exchange Rate Systems, Surveillance, and Advice," IMF Staff Papers, 55(3), 367-383.

Frankel, J., 1999, "No Single Currency Regime is Right for All Countries or at All Times," NBER Working Paper 7338 (Cambridge, MA: National Bureau of Economic Research).

Frankel, J. and A. Rose, 1996, "Currency Crashes in Emerging Markets: An Empirical Treatment,” Journal of International Economics, Vol. 41, pp. 351-366.

Frankel, J., S. Schmukler, and L. Serven, 2000, "Verifiability and the Vanishing Intermediate Exchange Rate Regime,” NBER Working Paper 7901 (Cambridge, MA: NBER).

Goldfajn, I., and R. Valdes, 1999, “The Aftermath of Appreciations," Quarterly Journal of Economics, 114(1), pp. 229-262

Ghosh, A., A. Gulde, and Holger Wolf, 2003, Exchange Rate Regimes: Choices and Consequences (Cambridge, MA: MIT Press).

Ghosh, A., B. Joshi, J. Kim, U. Ramakrishnan, A. Thomas, J. Zalduendo, 2008, "IMF Support and Crisis Prevention," IMF Occasional Paper 262 (Washington DC: IMF).

Ghosh, A., J. Ostry, and C. Tsangarides, 2010, "Exchange Rate Regime and the Stability of the International Monetary System," IMF Occasional Paper No. 270 (Washington DC: IMF).

Ghosh, A., M. Qureshi, and C. Tsangarides, 2013, “Is Exchange Rate Regime Really Irrelevant for External Adjustment?”Economic Letters, 118(1), 104-109.

Herrmann, S., 2009, "Do We Really Know that Flexible Exchange Rates Facilitate Current Account Adjustment? Some New Empirical Evidence for CEE Countries," Applied Economics Quarterly, 55, pp. 295-312.

IMF, 2008, Annual Report on Exchange Rate Arrangements and Exchange Rate Restrictions (Washington DC: International Monetary Fund).

Kaminsky, G., and C. Reinhart, 1999, “The Twin Crises: The Causes of Banking and Balance of Payments Problems," American Economic Review, 89(3), pp. 473-500.

Kass, G., 1980, “An Exploratory Technique for Investigating Large Quantities of Categorical Data," Applied Statistics, 29(2), pp. 119-127.

Klein, M., and J. Shambaugh, 2010, Exchange Rate Regimes in the Modern Era (Cambridge, MA: MIT Press). 
Laeven, L., and F. Valencia, 2012, "Systemic Banking Crises Database: An Update," IMF Working Paper No. WP/12/163 (Washington DC: International Monetary Fund).

Levy-Yeyati, E., and F. Sturzenegger, 2005, "Classifying Exchange Rate Regimes: Deeds vs. Words," European Economic Review, 49(6), 1603-1635.

Magud, N., C. Reinhart, and E. Vesperoni, 2011, "Capital Inflows, Exchange Rate Flexibility, and Credit Booms," NBER Working Paper No. 17670 (Cambridge, MA: NBER).

Masson, P., 2000, “Exchange Rate Regime Transitions,” IMF Working Paper WP/00/134 (Washington DC: International Monetary Fund).

Montiel, P. and C. Reinhart, 2001, “The Dynamics of Capital Movements to Emerging Economies during the 1990s," in S. Griffith-Jones, M. Montes, and A. Nasution (eds.), Shortterm Capital Flows and Economic Crises (Oxford: Oxford University Press, 2001).

Obstfeld, M., and K. Rogoff, 1995, “The Mirage of Fixed Exchange Rates," Journal of Economic Perspectives, 9(4), pp. 73-96.

Ostry, J., A. Ghosh, M. Chamon, and M. Qureshi, 2012, "Tools for Managing Financial Stability Risks," Journal of International Economics, 88(2), 407-421.

Reinhart, C., and K. Rogoff, 2004, "The Modern History of Exchange Rate Arrangements: A Reinterpretation," Quarterly Journal of Economics, 119(1), pp. 1-48.

Rogoff, R., A. Husain, A. Mody, R. Brooks, and N. Oomes, 2004, "Evolution and Performance of Exchange Rate Regimes," IMF Occasional Paper 229 (Washington DC: IMF).

Rose, A., 2011, "Exchange Rate Regimes in the Modern Era: Fixed, Floating, and Flaky," Journal of Economic Literature, 49(3), pp. 652-672.

Rosenberg, C. and M. Tirpák, 2008, "Determinants of Foreign Currency Borrowing in the New Member States of the EU," IMF Working Paper WP/08/173 (Washington DC: IMF).

Shambaugh, J., 2004, “The Effects of Fixed Exchange Rates on Monetary Policy," Quarterly Journal of Economics, 119(1), pp. 301-352.

Tornell, A., and A. Velasco, 2000, "Fixed versus Flexible Exchange Rates: Which Provides More Fiscal Discipline?” Journal of Monetary Economics, 45(2), pp. 399-436. 
Figure 1. Distribution of Exchange Rate Regimes in EMEs: IMF's De Facto Classification 1980-2011 (In percent)

(a) Aggregate classification

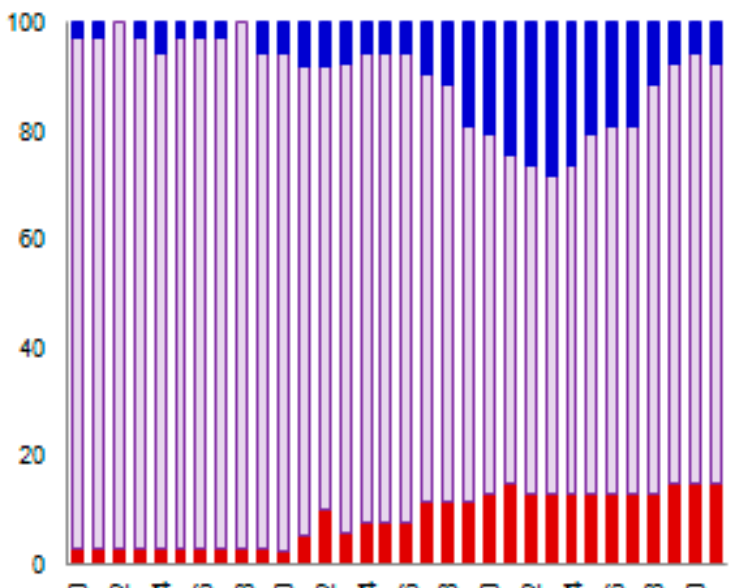

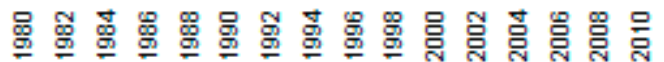

aloat

口Intermediate

aFixed

Source: Anderson (2008) and IMF's AREAER.

Note: Fixed=hard pegs; Intermediate=pegs to single currency.

basket pegs, horizontal band, crawling peg/band, and managed

floats; Float=independent floats. (b) Fine classification

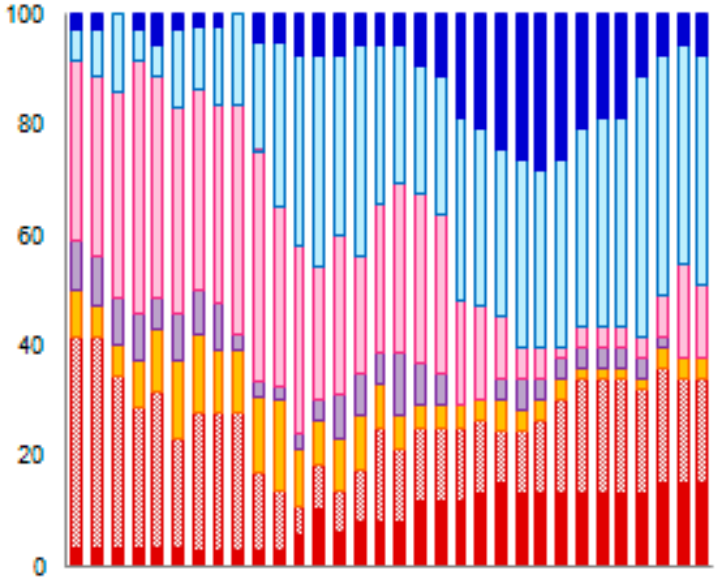

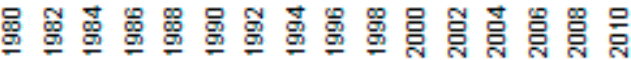

andependent float

पManaged float

口Crawling peg/band

口 Horizontal band

aBasket peg

बPeg to single currency

- Hard peg (no separate legal tender/currency board

Figure 2. Current Account Balance in EMEs: IMF's De Facto Classification 1980-2011 (In percent)

(a) Aggregate classification

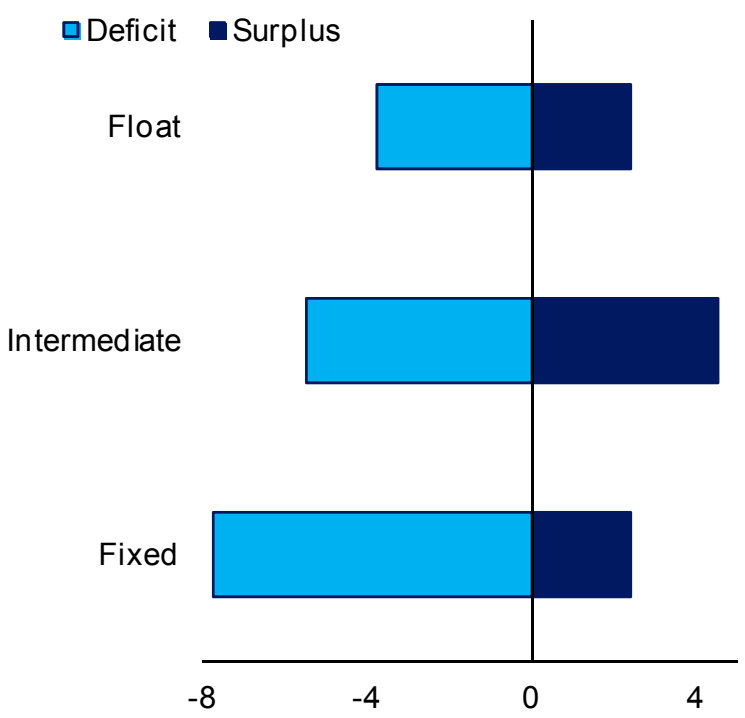

(b) Fine classification

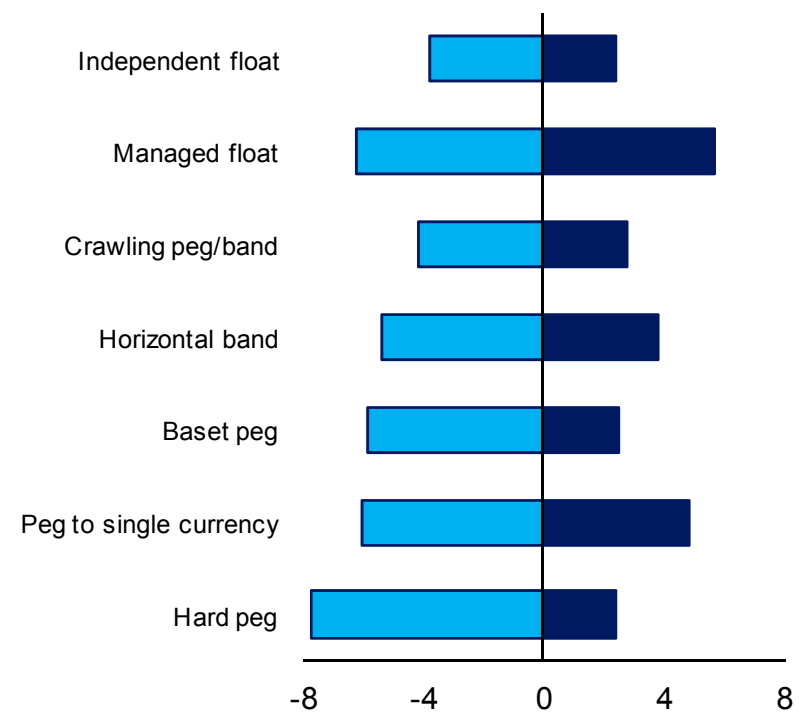

Source: Anderson (2008), IMF's AREAER and WEO databases.

Note: The figure depicts the average surplus and deficit under different exchange rate regimes in our sample of EMEs. Thus, e.g., panel (a) shows that fixed, intermediate and floating regimes have, on average, current account deficits of $-8,-6$ and -4 percent of GDP, respectively; and current account surpluses of about $2.5,4$, and 2.5 percent of GDP, respectively 
Figure 3. Binary Recursive Tree: Banking or Currency Crisis $1 /$

Crisis: 62 (7\%)

No Crisis: 766 (93\%)

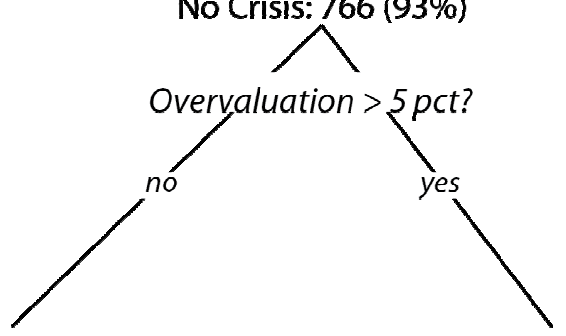

Crisis: 27 (4\%)

No Crisis: 684 (96\%)

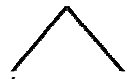

Credit Growth $>30$ pp in 3 years?<smiles>C[AlH]C</smiles>

Crisis: 22 (3\%)

Crisis: 5 (45\%)<smiles>C[AsH]1CC[As]1</smiles>

No Crisis: $678(97 \%)$

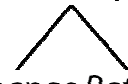

Greater Exchange Rate Flexibility?<smiles>C[10BH]C</smiles>

Crisis: 15 (2\%) No Crisis: 631 (98\%)

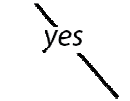

Crisis: 7 (13\%)

No Crisis: 47 (87\%)<smiles>C1CC1</smiles>

Crisis: 35 (30\%)

No Crisis: 82 (70\%)

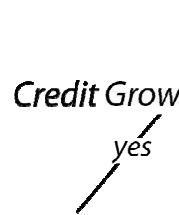

Crisis: 5 (100\%)

No Crisis: $0(0 \%)$

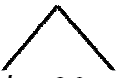


Figure 4. Binary Recursive Tree: Banking or Currency Crisis (countries with overvalued exchange rates) 1/

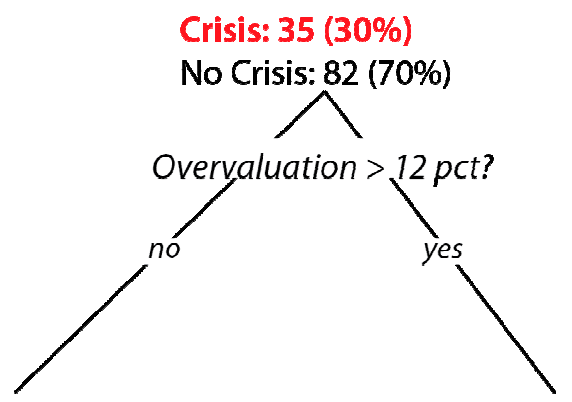

Crisis: 23 (24\%)

No Crisis: 72 (76\%)<smiles>CCC</smiles>

Crisis: 12 (55\%)

No Crisis: $10(45 \%)$
Greater Exch

Crisis: 6 (67\%)

No Crisis: 3 (33\%)
Crisis: $17(20 \%)$

No Crisis: $69(80 \%)$

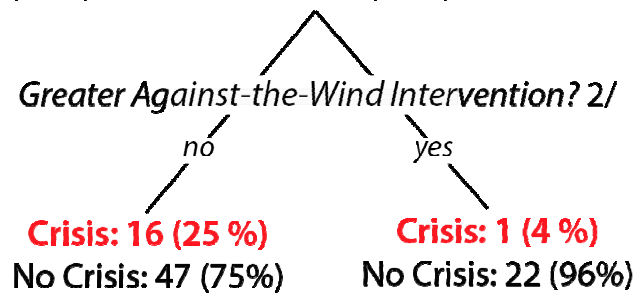

1/ Sample includes observations with overvalued exchange rates (REER deviation from trend in excess of 5 percent), excluding those observations identified as hard pegs or pure floats under both the IMF and RR classifications. The tree is constructed using the Improved CHAID algorithm in SAPINA software (with minimum size of nodes to split and leaves specified as 10 and 5 observations respectively, and the p-level for merging and splitting nodes specified as 0.05 ).

$2 /$ Purchase of FX in the face of overvalued currency 
Figure 5. Binary Recursive Tree: Banking or Currency Crisis (countries with overvalued exchange rates) 1/

Crisls: 35 (30\%)

No Crisis: 82 (70\%)

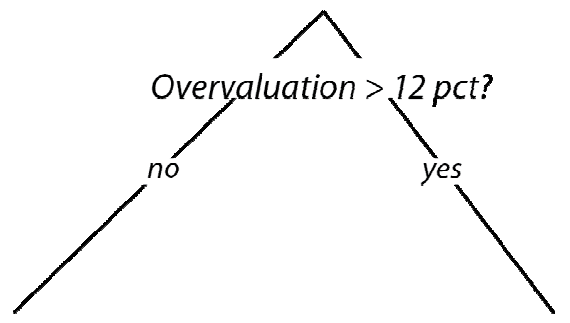

Crisis: $23(24 \%)$

No Crisis: 72 (76\%)

Crisis: 12 (55\%)

人

No Crisis: $10(45 \%)$

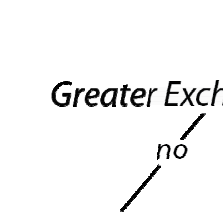

Crisis: 6 (67\%)

No Crisis: 3 (33\%)

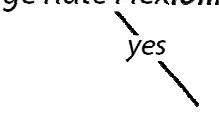

Crisis: 17 (20\%)

Crisis: $7(44 \%)$
No Crisis: $9(56 \%)$

No Crisis: 69 (80\%) No Crisis: 9 (56\%)

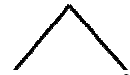

Crisis: 5 (83\%)

No Crisis: 1 (17\%)

1/ Sample includes observations with overvalued exchange rates (REER deviation from trend in excess of 5 percent), excluding those observations identified as hard pegs or pure floats under both the IMF and RR classificatlons. The tree is constructed using the Improved CHAID algorithm in SAPINA software (with minimum size of nodes to split and leaves specified as 10 and 5 observations respectively, and the $\mathrm{p}$-level for merging and splitting nodes specified as 0.05 ).

2/ Sale of FX to defend overvalued currency. 
Table 1. Transition Probabilities Matrix for EMEs: IMF's De Facto Aggregate Classification

(a) $1980-2011$

\begin{tabular}{lccc}
\hline & Fixed & Intermediate & Float \\
\cline { 2 - 4 } Fixed & 0.977 & 0.015 & 0.008 \\
Intermediate & 0.004 & 0.965 & 0.031 \\
Float & 0.018 & 0.195 & 0.787 \\
& & & \\
\hline Steady-state regime distribution & 0.194 & 0.697 & 0.108 \\
Regime distribution in 2011 & 0.151 & 0.774 & 0.075 \\
LR test statistic (fixed as an absorbing state) & 5.931 (p-value=0.084) & \\
LR test statistic (float as an absorbing state) & 61.934 (p-value=0.000) & \\
LR test statistic (fixed and float being a closed set) & 61.274 (p-value=0.000) & \\
Note: Fixed=hard pegs (no separate legal tender/currency board); Intermediate=pegs to single currency, \\
basket pegs, horizontal band, crawling peg/band, and managed floats; Float=independent floats.
\end{tabular}

(b) $2000-2011$

\begin{tabular}{lccc}
\hline & Fixed & Intermediate & Float \\
\cline { 2 - 4 } Fixed & 0.988 & 0.012 & 0.000 \\
Intermediate & 0.005 & 0.967 & 0.028 \\
Float & 0.008 & 0.140 & 0.851 \\
\hline Steady-state regime distribution & 0.311 & 0.580 & 0.109 \\
Regime distribution in 2011 & 0.151 & 0.774 & 0.075 \\
LR test statistic (fixed as an absorbing state) & 1.988 (p-value=0.635) & \\
LR test statistic (float as an absorbing state) & 33.179 (p-value=0.000) \\
LR test statistic (fixed and float being a closed set) & 33.479 (p-value=0.000) & \\
\hline
\end{tabular}


Table 2. Transition Probabilities Matrix for EMEs: IMF's De Facto Fine Classification

(a) $1980-2011$

\begin{tabular}{|c|c|c|c|c|c|c|c|}
\hline & Hard peg & $\begin{array}{l}\text { Peg to single } \\
\text { currency }\end{array}$ & $\begin{array}{c}\text { Basket } \\
\text { peg }\end{array}$ & $\begin{array}{l}\text { Horizontal } \\
\text { band }\end{array}$ & $\begin{array}{l}\text { Craw ling } \\
\text { peg/band }\end{array}$ & $\begin{array}{l}\text { Managed } \\
\text { float }\end{array}$ & $\begin{array}{c}\text { Independent } \\
\text { float }\end{array}$ \\
\hline Hard peg & 0.977 & 0.000 & 0.000 & 0.000 & 0.000 & 0.015 & 0.008 \\
\hline Peg to single currency & 0.008 & 0.751 & 0.016 & 0.012 & 0.080 & 0.120 & 0.012 \\
\hline Basket peg & 0.000 & 0.043 & 0.871 & 0.032 & 0.022 & 0.022 & 0.011 \\
\hline Horizontal band & 0.014 & 0.056 & 0.000 & 0.732 & 0.070 & 0.113 & 0.014 \\
\hline Craw ling peg/band & 0.000 & 0.055 & 0.003 & 0.010 & 0.846 & 0.048 & 0.039 \\
\hline Managed float & 0.002 & 0.067 & 0.007 & 0.015 & 0.037 & 0.827 & 0.044 \\
\hline Independent float & 0.018 & 0.018 & 0.000 & 0.000 & 0.000 & 0.177 & 0.787 \\
\hline Steady-state distribution & 0.195 & 0.142 & 0.040 & 0.034 & 0.169 & 0.307 & 0.114 \\
\hline Regime distribution in 2011 & 0.137 & 0.196 & 0.039 & 0.000 & 0.137 & 0.412 & 0.078 \\
\hline
\end{tabular}

(b) 2000-2011

\begin{tabular}{|c|c|c|c|c|c|c|c|}
\hline & Hard peg & $\begin{array}{l}\text { Peg to single } \\
\text { currency }\end{array}$ & $\begin{array}{c}\text { Basket } \\
\text { peg }\end{array}$ & $\begin{array}{c}\text { Horizontal } \\
\text { band }\end{array}$ & $\begin{array}{l}\text { Craw ling } \\
\text { peg/band }\end{array}$ & $\begin{array}{c}\text { Managed } \\
\text { float }\end{array}$ & $\begin{array}{c}\text { Independent } \\
\text { float }\end{array}$ \\
\hline Hard peg & 0.988 & 0.000 & 0.000 & 0.000 & 0.000 & 0.012 & 0.000 \\
\hline Peg to single currency & 0.010 & 0.819 & 0.010 & 0.010 & 0.067 & 0.086 & 0.000 \\
\hline Basket peg & 0.000 & 0.048 & 0.905 & 0.048 & 0.000 & 0.000 & 0.000 \\
\hline Horizontal band & 0.056 & 0.056 & 0.000 & 0.667 & 0.111 & 0.056 & 0.056 \\
\hline Craw ling peg/band & 0.000 & 0.094 & 0.000 & 0.019 & 0.717 & 0.113 & 0.057 \\
\hline Managed float & 0.000 & 0.061 & 0.004 & 0.013 & 0.013 & 0.874 & 0.035 \\
\hline Independent float & 0.008 & 0.000 & 0.000 & 0.000 & 0.000 & 0.140 & 0.851 \\
\hline Steady-state distribution & 0.315 & 0.152 & 0.029 & 0.024 & 0.060 & 0.315 & 0.105 \\
\hline Regime distribution in 2011 & 0.137 & 0.196 & 0.039 & 0.000 & 0.137 & 0.412 & 0.078 \\
\hline
\end{tabular}

Table 3. Vulnerabilities and Crisis in EMEs: IMF's De Facto Classification, 1980-2011 (In percent)

\begin{tabular}{|c|c|c|c|c|c|c|c|c|c|}
\hline & \multicolumn{3}{|c|}{ Financial vulnerabilities } & \multicolumn{2}{|c|}{ Macro vulnerabilities } & \multicolumn{4}{|c|}{ Crisis $^{a}$} \\
\hline & $\begin{array}{l}\text { Credit } \\
\text { boom }^{\text {b }}\end{array}$ & $\begin{array}{c}\text { Foreign } \\
\text { borrowing }\end{array}$ & $\begin{array}{c}\text { FX } \\
\text { lending }\end{array}$ & $\begin{array}{c}\text { Fiscal } \\
\text { balance }\end{array}$ & $\begin{array}{c}\text { REER } \\
\text { deviation }\end{array}$ & Bank & Currency & Debt & Growth \\
\hline & $(1)$ & $(2)$ & (3) & $(4)$ & (5) & (6) & (7) & (8) & (9) \\
\hline Hard pegs & 6.1 & 14.3 & 58.9 & -2.7 & 0.3 & 3.0 & 1.0 & 2.0 & 10.5 \\
\hline Intermediate & 2.4 & 9.4 & 36.1 & -3.6 & 0.2 & 4.7 & 5.2 & 1.9 & 4.4 \\
\hline Peg to single currency & 3.5 & 12.3 & 34.9 & -4.6 & 0.9 & 3.6 & 5.2 & 2.8 & 6.9 \\
\hline Basket peg & 8.8 & 10.7 & 49.2 & -1.9 & -0.2 & 5.4 & 1.1 & 1.1 & 8.3 \\
\hline Horizontal band & 5.1 & 9.9 & 44.5 & -4.5 & 0.6 & 7.0 & 2.8 & 1.4 & 3.4 \\
\hline Craw ling peg/band & 1.1 & 8.3 & 35.1 & -3.4 & 0.8 & 7.4 & 7.4 & 2.3 & 3.1 \\
\hline Managed float & 1.2 & 8.0 & 35.4 & -3.5 & -0.7 & 2.7 & 4.9 & 1.5 & 3.3 \\
\hline Independent float & 0.8 & 7.3 & 29.4 & -3.2 & -1.6 & 1.2 & 2.4 & 0.6 & 3.8 \\
\hline
\end{tabular}

a/ In percent of exchange rate regime observations.

b/ In percentage points. 
Table 4. Domestic Credit: IMF's De Facto Classification, 1980-2011

\begin{tabular}{|c|c|c|c|c|c|c|}
\hline & \multicolumn{3}{|c|}{$\begin{array}{c}\text { Change in domestic } \\
\text { credit }\end{array}$} & \multicolumn{3}{|c|}{$\begin{array}{l}\text { Change in domestic credit } \\
\text { (expansion) }\end{array}$} \\
\hline & $(1)$ & (2) & (3) & (4) & (5) & (6) \\
\hline Hard peg & $\begin{array}{l}4.332^{*} \\
(2.509)\end{array}$ & $\begin{array}{c}4.345 \\
(2.664)\end{array}$ & $\begin{array}{c}2.614 \\
(2.304)\end{array}$ & $\begin{array}{l}4.086^{*} \\
(2.194)\end{array}$ & $\begin{array}{l}4.023^{*} \\
(2.274)\end{array}$ & $\begin{array}{c}0.736 \\
(1.703)\end{array}$ \\
\hline Intermediate & $\begin{array}{c}2.432 \\
(2.133)\end{array}$ & & & $\begin{array}{l}3.104^{* *} \\
(1.313)\end{array}$ & & \\
\hline Peg to single currency & & $\begin{array}{c}2.588 \\
(2.643)\end{array}$ & $\begin{array}{c}2.372 \\
(2.528)\end{array}$ & & $\begin{array}{l}5.214^{\star * *} \\
(1.764)\end{array}$ & $\begin{array}{c}0.537 \\
(1.447)\end{array}$ \\
\hline Basket peg & & $\begin{array}{l}10.263^{* *} \\
(4.112)\end{array}$ & $\begin{array}{l}9.201^{* *} \\
(3.519)\end{array}$ & & $\begin{array}{l}8.843^{* * *} \\
(1.946)\end{array}$ & $\begin{array}{l}5.367^{* * *} \\
(1.209)\end{array}$ \\
\hline Horizontal band & & $\begin{array}{l}5.051^{* *} \\
(2.473)\end{array}$ & $\begin{array}{l}4.913^{* *} \\
(2.362)\end{array}$ & & $\begin{array}{l}3.041^{* *} \\
(1.512)\end{array}$ & $\begin{array}{c}1.907 \\
(1.489)\end{array}$ \\
\hline Craw ling peg/band & & $\begin{array}{c}2.322 \\
(2.580)\end{array}$ & $\begin{array}{c}1.021 \\
(2.495)\end{array}$ & & $\begin{array}{l}2.780 \\
(1.694)\end{array}$ & $\begin{array}{l}-0.130 \\
(1.341)\end{array}$ \\
\hline Managed float & & $\begin{array}{l}1.490 \\
(2.171)\end{array}$ & $\begin{array}{c}0.398 \\
(2.039)\end{array}$ & & $\begin{array}{c}1.490 \\
(1.497)\end{array}$ & $\begin{array}{l}-0.252 \\
(1.265)\end{array}$ \\
\hline Real GDP grow th & & & $\begin{array}{l}0.418^{* * *} \\
(0.141)\end{array}$ & & & $\begin{array}{l}0.288^{* * *} \\
(0.105)\end{array}$ \\
\hline Inflation & & & $\begin{array}{l}-0.062 \\
(0.068)\end{array}$ & & & $\begin{array}{c}0.170 \\
(0.111)\end{array}$ \\
\hline Initial domestic credit/GDP & & & $\begin{array}{c}-0.162^{* * *} \\
(0.035)\end{array}$ & & & $\begin{array}{l}0.111^{* * *} \\
(0.040)\end{array}$ \\
\hline Net financial flow s/GDP & & & $\begin{array}{l}0.287^{\star *} \\
(0.126)\end{array}$ & & & $\begin{array}{l}0.333^{\star \star *} \\
(0.117)\end{array}$ \\
\hline Bank foreign liabilities/GDP & & & $\begin{array}{l}0.165^{\star *} \\
(0.067)\end{array}$ & & & $\begin{array}{l}0.146^{\star *} \\
(0.063)\end{array}$ \\
\hline Real GDP per capita (log) & $\begin{array}{c}-0.302 \\
(0.925)\end{array}$ & $\begin{array}{l}-0.486 \\
(0.947)\end{array}$ & $\begin{array}{c}1.097 \\
(1.000)\end{array}$ & $\begin{array}{c}1.312 \\
(1.225)\end{array}$ & $\begin{array}{c}1.239 \\
(1.159)\end{array}$ & $\begin{array}{l}-1.383^{*} \\
(0.808)\end{array}$ \\
\hline Region-fixed effects & Yes & Yes & Yes & Yes & Yes & Yes \\
\hline Year effects & Yes & Yes & Yes & Yes & Yes & Yes \\
\hline Observations & 1,010 & 1,010 & 1,010 & 646 & 646 & 646 \\
\hline R-squared & 0.129 & 0.151 & 0.276 & 0.185 & 0.227 & 0.391 \\
\hline No. of countries & 51 & 51 & 51 & 51 & 51 & 51 \\
\hline $\begin{array}{l}\text { Test of coeff. equality w ith } \\
\text { managed float ( } p \text {-value): }\end{array}$ & & & & & & \\
\hline Hard peg & & 0.227 & 0.235 & & 0.243 & 0.543 \\
\hline Peg to single currency & & 0.605 & 0.322 & & 0.027 & 0.643 \\
\hline Basket peg & & 0.057 & 0.016 & & 0.002 & 0.000 \\
\hline Horizontal band & & 0.079 & 0.013 & & 0.397 & 0.198 \\
\hline Craw ling peg/band & & 0.636 & 0.703 & & 0.416 & 0.909 \\
\hline $\begin{array}{l}\text { Notes: Dependent variable is cum } \\
\text { difference between } t \text { and } t-3 \text { ) in co } \\
\text { The reference catego ry is free flo } \\
\text { See Appendix B for variable defin } \\
\text { standard errors at co untry level re } \\
\text { levels, respectively. }\end{array}$ & $\begin{array}{l}\text { All variable } \\
\text { ons and dat } \\
\text { orted in par }\end{array}$ & $\begin{array}{l}\text { ge in private } \\
\text { mple restric } \\
\text { les (except } f \\
\text { ta sources. }\end{array}$ & $\begin{array}{l}\text { e sector cr } \\
\text { ted to only } \\
\text { for initial cr } \\
\text { Constant }\end{array}$ & $\begin{array}{l}\text { GDP ratio } \\
\text { ded in all }\end{array}$ & $\begin{array}{l}\text { over } 3 \text { yea } \\
\text { in colum } \\
\text { e lagged } \\
\text { cifications }\end{array}$ & $\begin{array}{l}\text { (i.e., } \\
(4)-(6) . \\
\text { e period. } \\
\text { lustered } \\
10 \text { percent }\end{array}$ \\
\hline
\end{tabular}


Table 5. Bank Foreign Borrowing: IMF's De Facto Classification, 1980-2011

\begin{tabular}{|c|c|c|c|c|c|c|}
\hline & (1) & (2) & (3) & (4) & (5) & (6) \\
\hline Hard peg & $\begin{array}{l}7.795^{\star *} \\
(3.117)\end{array}$ & $\begin{array}{l}7.828^{* *} \\
(3.137)\end{array}$ & $\begin{array}{l}6.628^{* *} \\
(2.554)\end{array}$ & $\begin{array}{l}5.376^{*} \\
(2.831)\end{array}$ & $\begin{array}{l}4.881^{*} \\
(2.806)\end{array}$ & $\begin{array}{l}3.034 \\
(3.495)\end{array}$ \\
\hline Intermediate & $\begin{array}{l}4.131^{* *} \\
(1.855)\end{array}$ & & & & & \\
\hline Peg to single currency & & $\begin{array}{l}8.277^{* *} \\
(4.092)\end{array}$ & $\begin{array}{l}6.062 \\
(3.642)\end{array}$ & $\begin{array}{l}9.176^{*} \\
(4.606)\end{array}$ & $\begin{array}{l}8.206^{*} \\
(4.606)\end{array}$ & $\begin{array}{l}10.001^{\text {** }} \\
(4.569)\end{array}$ \\
\hline Basket peg & & $\begin{array}{l}5.646 \\
(6.006)\end{array}$ & $\begin{array}{l}3.513 \\
(5.972)\end{array}$ & $\begin{array}{l}5.409 \\
(10.434)\end{array}$ & $\begin{array}{l}5.266 \\
(10.887)\end{array}$ & $\begin{array}{l}5.916 \\
(10.003)\end{array}$ \\
\hline Horizontal band & & $\begin{array}{l}3.660^{*} \\
(1.988)\end{array}$ & $\begin{array}{l}2.785 \\
(2.007)\end{array}$ & $\begin{array}{l}1.864 \\
(2.621)\end{array}$ & $\begin{array}{l}1.267 \\
(2.746)\end{array}$ & $\begin{array}{l}-0.348 \\
(3.112)\end{array}$ \\
\hline Craw ling peg/band & & $\begin{array}{l}4.348^{* *} \\
(1.941)\end{array}$ & $\begin{array}{l}4.281^{*} \\
(2.145)\end{array}$ & $\begin{array}{l}3.261 \\
(2.359)\end{array}$ & $\begin{array}{l}2.276 \\
(2.516)\end{array}$ & $\begin{array}{l}3.641 \\
(2.508)\end{array}$ \\
\hline Managed float & & $\begin{array}{l}1.879 \\
(1.244)\end{array}$ & $\begin{array}{l}1.765 \\
(1.319)\end{array}$ & $\begin{array}{l}2.434 \\
(1.732)\end{array}$ & $\begin{array}{l}1.957 \\
(1.694)\end{array}$ & $\begin{array}{l}2.858 \\
(1.802)\end{array}$ \\
\hline Real GDP grow th & & & $\begin{array}{l}-0.062 \\
(0.101)\end{array}$ & $\begin{array}{l}-0.101 \\
(0.155)\end{array}$ & $\begin{array}{l}-0.118 \\
(0.177)\end{array}$ & $\begin{array}{l}-0.177 \\
(0.171)\end{array}$ \\
\hline REER deviation & & & $\begin{array}{l}-1.136 \\
(2.675)\end{array}$ & $\begin{array}{l}2.107 \\
(3.981)\end{array}$ & $\begin{array}{l}4.724 \\
(4.083)\end{array}$ & $\begin{array}{l}1.862 \\
(4.824)\end{array}$ \\
\hline Domestic credit/GDP & & & $\begin{array}{l}0.156^{\star * *} \\
(0.043)\end{array}$ & $\begin{array}{l}0.147^{* * *} \\
(0.047)\end{array}$ & $\begin{array}{l}0.153^{* * *} \\
(0.049)\end{array}$ & $\begin{array}{l}0.124^{* *} \\
(0.048)\end{array}$ \\
\hline Inflow controls index & & & & $\begin{array}{l}-6.594^{*} \\
(3.714)\end{array}$ & & $\begin{array}{l}-3.578 \\
(3.490)\end{array}$ \\
\hline Restrictions on FX lending & & & & & & $\begin{array}{l}-1.261 \\
(2.673)\end{array}$ \\
\hline $\begin{array}{l}\text { Restrictions on purchase of } \\
\text { locally issued FX securities }\end{array}$ & & & & & & $\begin{array}{l}-2.821 \\
(1.860)\end{array}$ \\
\hline $\begin{array}{l}\text { Differential treatment of FX } \\
\text { deposit accounts }\end{array}$ & & & & & & $\begin{array}{l}-1.557 \\
(2.482)\end{array}$ \\
\hline Open FX position limits & & & & & $\begin{array}{l}-5.223^{* *} \\
(2.560)\end{array}$ & $\begin{array}{l}-4.058^{*} \\
(2.190)\end{array}$ \\
\hline Real GDP per capita (log) & $\begin{array}{l}5.708^{* * *} \\
(1.560)\end{array}$ & $\begin{array}{l}5.964^{* * *} \\
(1.582)\end{array}$ & $\begin{array}{l}3.542^{* *} \\
(1.427)\end{array}$ & $\begin{array}{l}4.239^{\star *} \\
(1.871)\end{array}$ & $\begin{array}{l}4.492^{\star *} \\
(1.895)\end{array}$ & $\begin{array}{l}4.928^{\star *} \\
(2.042)\end{array}$ \\
\hline Region-fixed effects & Yes & Yes & Yes & Yes & Yes & Yes \\
\hline Year effects & Yes & Yes & Yes & Yes & Yes & Yes \\
\hline Observations & 1,237 & 1,237 & 1,237 & 761 & 729 & 664 \\
\hline R-squared & 0.208 & 0.242 & 0.327 & 0.417 & 0.404 & 0.437 \\
\hline $\begin{array}{l}\text { No. of countries } \\
\text { Test for coefficient equality } \\
w \text { ith managed float ( } p \text {-value) }\end{array}$ & 50 & 50 & 50 & 50 & 50 & 50 \\
\hline Hard peg & & 0.070 & 0.076 & 0.316 & 0.317 & 0.963 \\
\hline Peg to single currency & & 0.094 & 0.198 & 0.106 & 0.136 & 0.079 \\
\hline Basket peg & & 0.509 & 0.756 & 0.770 & 0.758 & 0.754 \\
\hline Horizontal band & & 0.330 & 0.546 & 0.789 & 0.762 & 0.250 \\
\hline Craw ling peg/band & & 0.167 & 0.153 & 0.658 & 0.872 & 0.704 \\
\hline
\end{tabular}


Table 6. FX Lending: IMF's De Facto Classification, 1995-2011

\begin{tabular}{|c|c|c|c|c|c|c|}
\hline & (1) & (2) & (3) & (4) & (5) & (6) \\
\hline Hard peg & $\begin{array}{l}20.379^{* *} \\
(9.286)\end{array}$ & $\begin{array}{l}20.505^{* *} \\
(9.549)\end{array}$ & $\begin{array}{c}9.645 \\
(8.983)\end{array}$ & $\begin{array}{l}4.154 \\
(9.450)\end{array}$ & $\begin{array}{l}2.360 \\
(9.430)\end{array}$ & $\begin{array}{l}2.351 \\
(9.614)\end{array}$ \\
\hline Intermediate & $\begin{array}{c}3.485 \\
(5.822)\end{array}$ & & & & & \\
\hline Peg to single currency & & $\begin{array}{c}0.252 \\
(8.715)\end{array}$ & $\begin{array}{l}-8.945 \\
(6.236)\end{array}$ & $\begin{array}{l}-6.837 \\
(6.360)\end{array}$ & $\begin{array}{l}-7.641 \\
(5.554)\end{array}$ & $\begin{array}{l}-6.480 \\
(6.190)\end{array}$ \\
\hline Basket peg & & $\begin{array}{l}14.842^{* *} \\
(7.282)\end{array}$ & $\begin{array}{l}-5.925 \\
(6.588)\end{array}$ & $\begin{array}{l}-10.436 \\
(7.423)\end{array}$ & $\begin{array}{l}-13.978^{*} \\
(7.137)\end{array}$ & $\begin{array}{l}-13.371^{*} \\
(7.439)\end{array}$ \\
\hline Horizontal band & & $\begin{array}{l}-3.020 \\
(6.858)\end{array}$ & $\begin{array}{l}-5.926 \\
(5.979)\end{array}$ & $\begin{array}{l}-8.194 \\
(5.771)\end{array}$ & $\begin{array}{l}-9.681 \\
(6.033)\end{array}$ & $\begin{array}{l}-9.538 \\
(6.961)\end{array}$ \\
\hline Craw ling peg/band & & $\begin{array}{c}4.537 \\
(7.255)\end{array}$ & $\begin{array}{c}2.625 \\
(6.447)\end{array}$ & $\begin{array}{l}2.430 \\
(5.667)\end{array}$ & $\begin{array}{l}-1.687 \\
(5.801)\end{array}$ & $\begin{array}{l}-2.540 \\
(5.740)\end{array}$ \\
\hline Managed float & & $\begin{array}{c}4.188 \\
(5.860)\end{array}$ & $\begin{array}{c}1.666 \\
(5.202)\end{array}$ & $\begin{array}{l}2.141 \\
(5.105)\end{array}$ & $\begin{array}{l}0.631 \\
(4.951)\end{array}$ & $\begin{array}{l}0.651 \\
(4.915)\end{array}$ \\
\hline Real GDP grow th & & & $\begin{array}{l}-0.144 \\
(0.308)\end{array}$ & $\begin{array}{l}-0.181 \\
(0.308)\end{array}$ & $\begin{array}{l}-0.141 \\
(0.324)\end{array}$ & $\begin{array}{l}-0.193 \\
(0.325)\end{array}$ \\
\hline Inflation & & & $\begin{array}{l}-0.148 \\
(0.161)\end{array}$ & $\begin{array}{l}-0.131 \\
(0.160)\end{array}$ & $\begin{array}{l}-0.017 \\
(0.171)\end{array}$ & $\begin{array}{l}-0.086 \\
(0.185)\end{array}$ \\
\hline Net financial flow s/GDP & & & $\begin{array}{l}0.671^{* * *} \\
(0.222)\end{array}$ & $\begin{array}{l}0.671^{* * *} \\
(0.240)\end{array}$ & $\begin{array}{l}0.681^{* * *} \\
(0.233)\end{array}$ & $\begin{array}{l}0.681^{* * *} \\
(0.229)\end{array}$ \\
\hline Bank foreign liabilities/GDP & & & $\begin{array}{c}0.716^{* * *} \\
(0.189)\end{array}$ & $\begin{array}{l}0.676^{\star * *} \\
(0.202)\end{array}$ & $\begin{array}{l}0.686^{* * *} \\
(0.181)\end{array}$ & $\begin{array}{l}0.668^{* * *} \\
(0.176)\end{array}$ \\
\hline Inflow controls index & & & & $\begin{array}{l}-13.791^{*} \\
(8.036)\end{array}$ & & $\begin{array}{l}-9.055 \\
(8.301)\end{array}$ \\
\hline Restrictions on FX lending & & & & & $\begin{array}{l}-13.805^{* *} \\
(5.399)\end{array}$ & $\begin{array}{l}-11.362^{*} \\
(5.966)\end{array}$ \\
\hline $\begin{array}{l}\text { Restrictions on purchase of } \\
\text { locally issued FX securities }\end{array}$ & & & & & & $\begin{array}{l}0.020 \\
(4.665)\end{array}$ \\
\hline Differential treatment of FX & & & & & & 4.271 \\
\hline deposit accounts & & & & & & $(4.818)$ \\
\hline Open FX position limits & & & & & & $\begin{array}{l}1.267 \\
(5.222)\end{array}$ \\
\hline Real GDP per capita (log) & $\begin{array}{l}-4.476 \\
(4.362)\end{array}$ & $\begin{array}{l}-4.625 \\
(4.323)\end{array}$ & $\begin{array}{c}-9.733^{* * *} \\
(3.551)\end{array}$ & $\begin{array}{l}-10.029 \\
(3.504)\end{array}$ & $\begin{array}{l}-10.268^{* * *} \\
(3.309)\end{array}$ & $\begin{array}{l}-9.769^{* * *} \\
(3.164)\end{array}$ \\
\hline Region-fixed effects & Yes & Yes & Yes & Yes & Yes & Yes \\
\hline Year effects & Yes & Yes & Yes & Yes & Yes & Yes \\
\hline Observations & 571 & 571 & 571 & 548 & 539 & 516 \\
\hline R-squared & 0.351 & 0.360 & 0.507 & 0.534 & 0.571 & 0.570 \\
\hline $\begin{array}{l}\text { No. of countries } \\
\text { Test for coefficient equality } \\
w \text { ith managed float ( } p \text {-value) }\end{array}$ & 44 & 44 & 44 & 43 & 44 & 43 \\
\hline Hard peg & & 0.093 & 0.351 & 0.828 & 0.857 & 0.858 \\
\hline Peg to single currency & & 0.593 & 0.052 & 0.130 & 0.083 & 0.172 \\
\hline Basket peg & & 0.154 & 0.199 & 0.079 & 0.041 & 0.050 \\
\hline Horizontal band & & 0.204 & 0.110 & 0.024 & 0.051 & 0.082 \\
\hline Craw ling peg/band & & 0.953 & 0.853 & 0.952 & 0.657 & 0.532 \\
\hline
\end{tabular}


Table 7. Fiscal Balance and REER Deviation: IMF's De Facto Classification, 1980-2011

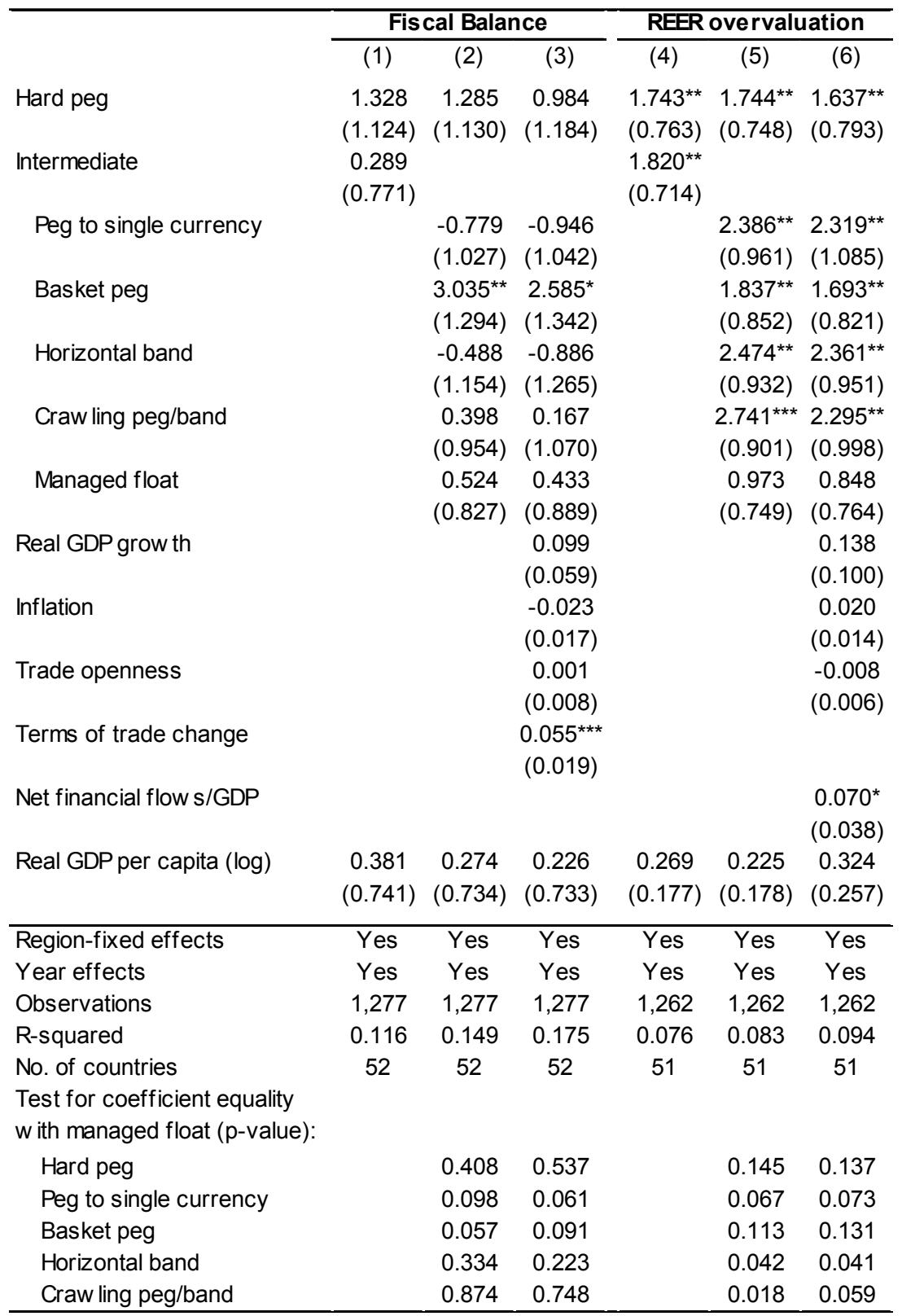

Notes: Dependent variable is general government fiscal balance to GDP (in percent) in cols. [1]-[3] and REER deviation from trend (in percent) in cols. [4]-[6]. The reference category is free float. All variables (except for terms of trade change) are lagged one period. Constant included in all specifications. Clustered standard erro rs at co untry level reported in parentheses. ${ }^{* * *},{ }^{* *}$ and * indicate significance at 1,5 and 10 percent levels, respectively. 
Table 8. Current Account Reversals: IMF's De Facto Classification, 1980-2011 (In percent of GDP)

\begin{tabular}{|c|c|c|c|c|c|}
\hline & & $\begin{array}{c}\text { Prior } \\
\text { balance }\end{array}$ & $\begin{array}{c}\text { Upper } \\
\text { quartile }\end{array}$ & $\begin{array}{c}\text { Lower } \\
\text { quartile }\end{array}$ & $\begin{array}{c}\text { Reversal } \\
\text { probability }\end{array}$ \\
\hline & & $(1)$ & (2) & (3) & (4) \\
\hline \multicolumn{6}{|l|}{ Surplus } \\
\hline & Fixed & 4.0 & 4.0 & 4.0 & 0.9 \\
\hline & Intermediate & 10.3 & 11.9 & 5.3 & 3.2 \\
\hline & Peg to single currency & 10.1 & 11.5 & 7.2 & 3.5 \\
\hline & Basket peg & 6.6 & 6.6 & 6.6 & 1.1 \\
\hline & Horizontal band & 6.9 & 9.2 & 4.6 & 5.6 \\
\hline & Craw ling peg/band & 7.6 & 10.1 & 5.1 & 2.2 \\
\hline & Managed float & 12.6 & 17.3 & 5.5 & 3.7 \\
\hline & Float & 6.9 & 11.9 & 4.2 & 1.8 \\
\hline \multicolumn{6}{|l|}{ Deficit } \\
\hline & Fixed & -15.9 & -7.1 & -19.2 & $9.3^{* * *}$ \\
\hline & Intermediate & -11.5 & -6.4 & -13.1 & $7.3^{\star \star \star}$ \\
\hline & Peg to single currency & -11.4 & -8.5 & -13.6 & $8.5^{* * *}$ \\
\hline & Basket peg & -11.0 & -9.8 & -11.6 & 5.3 \\
\hline & Horizontal band & -9.3 & -7.4 & -12.3 & $9.9^{* * *}$ \\
\hline & Craw ling peg/band & -8.9 & -5.6 & -9.2 & $7.2^{\star *}$ \\
\hline & Managed float & -14.5 & -5.5 & -19.8 & $6.6^{* *}$ \\
\hline & Float & -6.7 & -4.2 & -9.9 & 1.8 \\
\hline
\end{tabular}

Table 9. Crisis Occurrence in EMEs: 1980-2011 (In percent of crisis observations)

\begin{tabular}{lccccc}
\hline & Bank & Currency & Debt & Growth & $\begin{array}{c}\text { Total no. of crisis } \\
\text { observations }\end{array}$ \\
\hline Bank & $\ldots$ & 27.6 & 13.8 & 19.0 & 58 \\
Currency & 43.8 & $\ldots$ & 21.9 & 29.7 & 64 \\
Debt & 56.0 & 68.0 & $\ldots$ & 12.0 & 25 \\
Growth & 31.1 & 32.8 & 8.2 & 11.5 & 61
\end{tabular}


Table 10. Banking and Currency Crises: IMF's De Facto Classification, 1980-2011

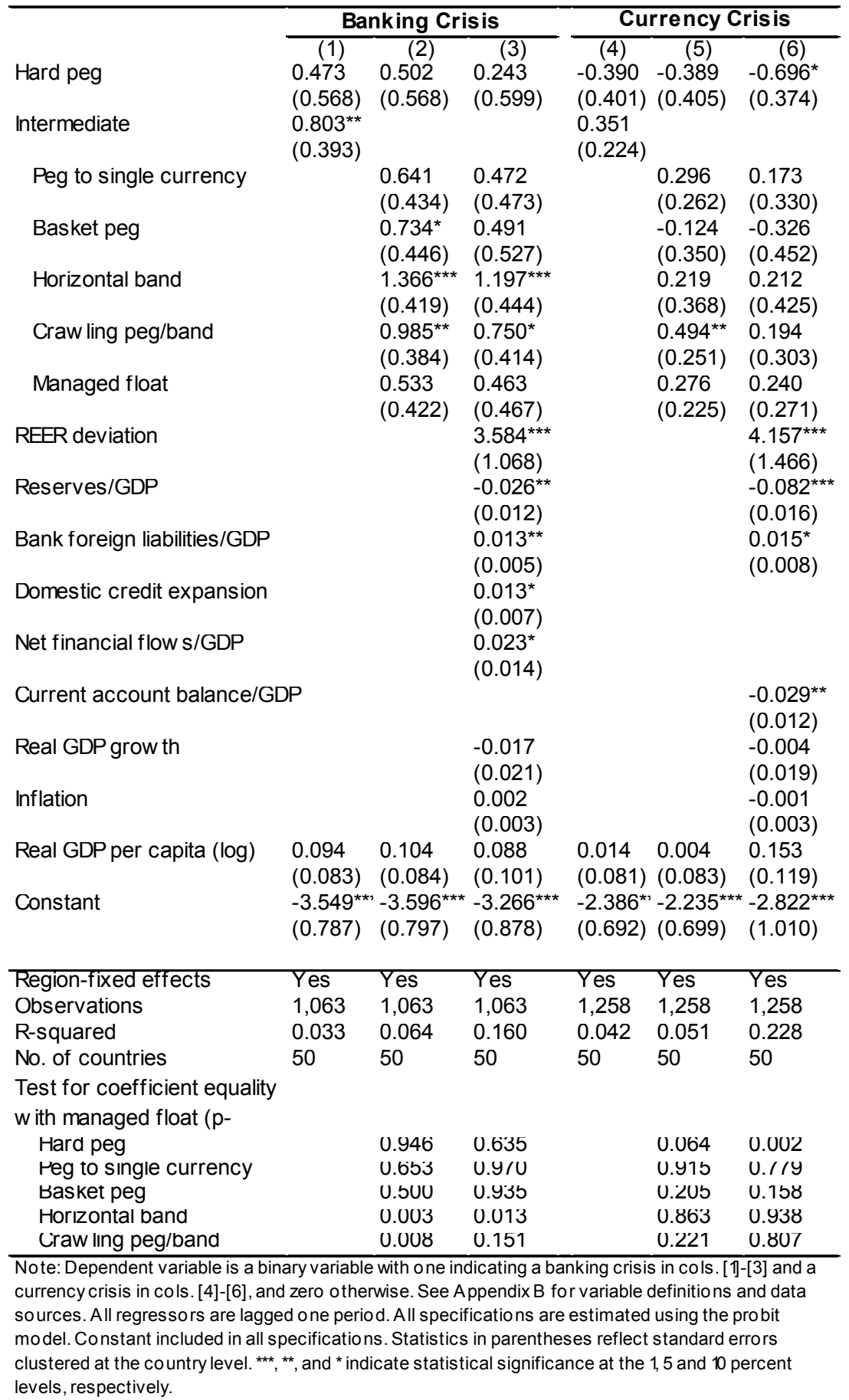


Table 11. Sovereign Debt Crisis and Growth Collapses: IMF's De Facto Classification, 1980-2011

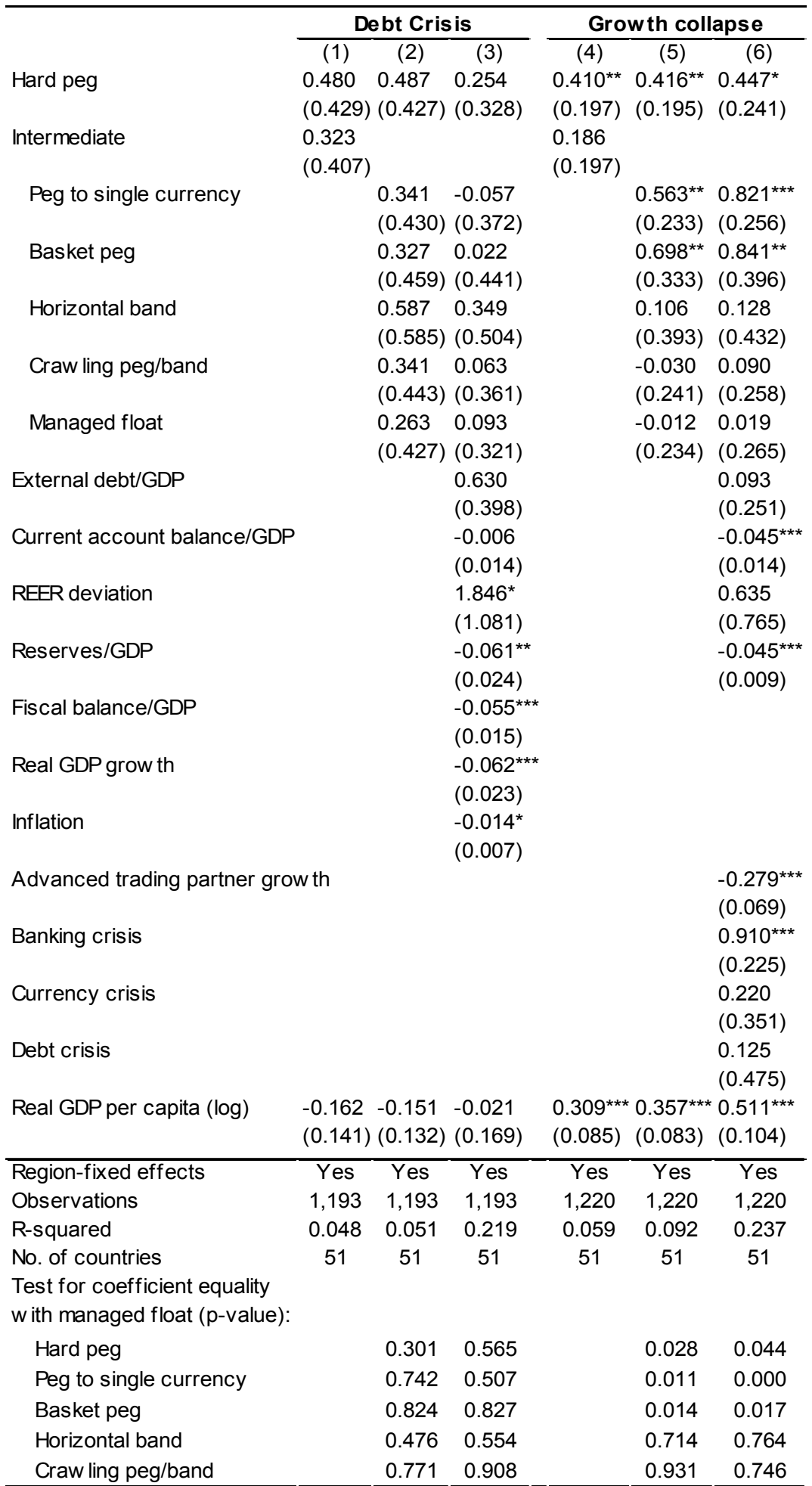

Note: Dependent variable is a binary variable with one indicating a soverein debt crisis in cols. [1][3] and gro wth collapse in cols. [4]-[6], and zero otherwise. See Appendix B for variable definitions and data sources. All regressors (except for trading partner growth) are lagged one period. All specifications are estimated using the probit model. Constant included in all specifications. Statistics in parentheses reflect standard erro rs clustered at the country level. ${ }^{* \star *},{ }^{* \star}$, and * indicate statistical significance at the 1,5 and 10 percent levels, respectively. 
Appendix A: Exchange Rate Regimes: De JuRe and RR Classifications

Figure A1. Distribution of Exchange Rate Regimes in EMs: IMF's De Jure Classification 1980-2011, (In percent)

(a) Aggregate classification

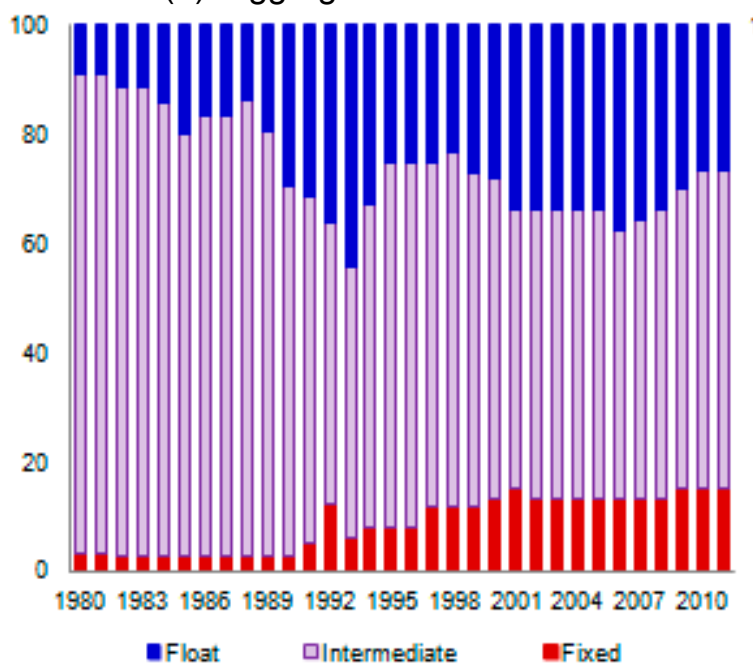

Source: Anderson (2008) and IMF's AREAER.

Note: Fixed=hard pegs; Intermediate=pegs to single currency,

basket pegs, horizontal band, crawling peg/band, and managed

floats; Float=independent floats. (b) Fine classification

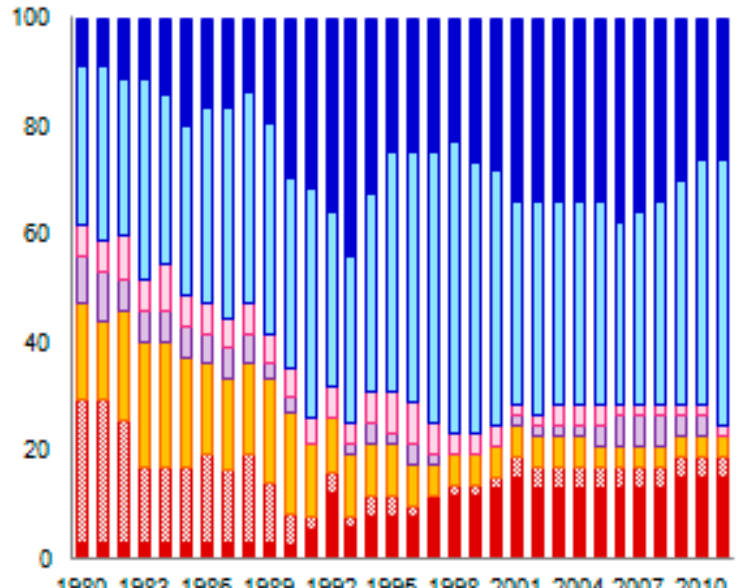

- Independent float

- Managed float

口Crawling peg/band

口Horizontal band

口Basket peg

․ㅏㄹ Peg to single currency

- Hard peg (no separate legal tender/currency board

Figure A2. Distribution of Exchange Rate Regimes in EMs: RR's De Facto Classification 1980-2010, (In percent)

(a) Aggregate classification

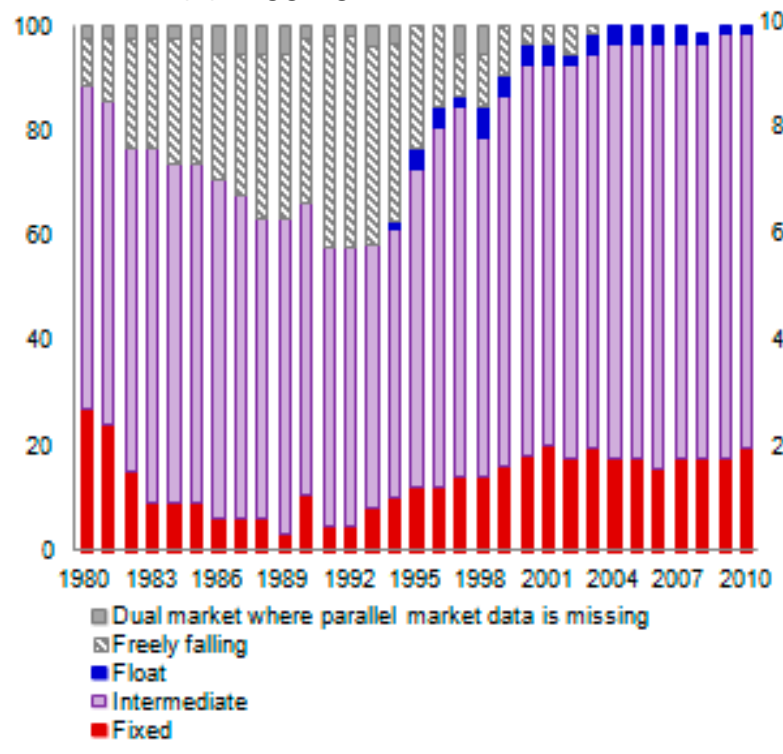

Source: Ilzetzki, Reinhart and Rogoff (2008).

Note: Fixed includes no separate legal tender, pre-announced peg and currency board; Intermediate includes pre-announced

horizontal band $s+i-2 \%$, de facto peg. pre-announced crawling peg. pre-announced crawling $\leq+-2 \%$, de facto crawling peg, de facto crawling band $s+\gamma-2 \%$; pre-announced crawling band $\mathrm{z}+/-5 \%$, de facto crawling band $s+1-5 \%$, moving band $s+1-2 \%$, and managed float; Float includes free float. (b) Fine classification

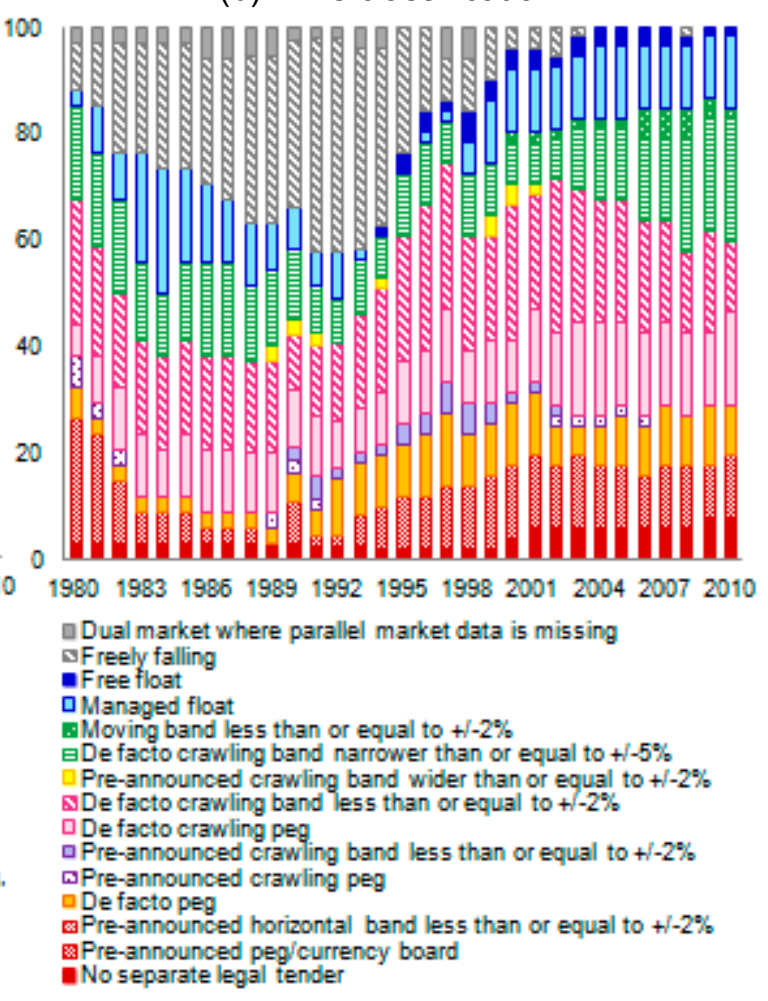


Table A1. List of Countries in the Sample

\begin{tabular}{lll}
\hline Albania & Estonia & Panama \\
Algeria & Georgia & Peru \\
Argentina & Guatemala & Philippines \\
Armenia & Hungary & Poland \\
Belarus & India & Romania \\
Bosnia \& Herzegovina & Indonesia & Russian Federation \\
Brazil & Jamaica & Serbia, Republic of \\
Bulgaria & Jordan & Slovak Republic \\
Chile & Kazakhstan & South Africa \\
China & Korea, Republic of & Sri Lanka \\
Colombia & Latvia & Thailand \\
Costa Rica & Lebanon & Tunisia \\
Croatia & Lithuania & Turkey \\
Czech Republic & Macedonia, FYR & Ukraine \\
Dominican Republic & Malaysia & Uruguay \\
Ecuador & Mexico & Venezuela \\
Egypt & Morocco & Vietnam \\
E Salvador & Pakistan & \\
\hline
\end{tabular}

Table A2. Transition Probabilities Matrix for EMs: IMF's De Jure Classification, 1980-2011

(a) Aggregate classification

\begin{tabular}{lccc}
\hline & Fixed & Intermediate & Float \\
\cline { 2 - 4 } Fixed & 0.970 & 0.008 & 0.023 \\
Intermediate & 0.004 & 0.959 & 0.037 \\
Float & 0.008 & 0.067 & 0.925 \\
Steady-state regime distribution & 0.157 & 0.534 & 0.309 \\
Regime distribution in 2011 & 0.151 & 0.585 & 0.264 \\
\hline
\end{tabular}

Note: Fixed=hard pegs (no separate legal tender/currency board); Intermediate=pegs to single currency, basket pegs, horizontal band, crawling peg/band, and managed floats; Float=independent floats.

(b) Fine classification

\begin{tabular}{lccccccc}
\hline & Hard peg & $\begin{array}{c}\text { Peg to single } \\
\text { currency }\end{array}$ & $\begin{array}{c}\text { Basket } \\
\text { peg }\end{array}$ & $\begin{array}{c}\text { Horizontal } \\
\text { band }\end{array}$ & $\begin{array}{c}\text { Craw ling } \\
\text { peg/band }\end{array}$ & $\begin{array}{c}\text { Managed } \\
\text { float }\end{array}$ & $\begin{array}{c}\text { Independent } \\
\text { float }\end{array}$ \\
\cline { 2 - 7 } Hard peg & 0.970 & 0.000 & 0.000 & 0.000 & 0.000 & 0.008 & 0.023 \\
Peg to single currency & 0.010 & 0.771 & 0.010 & 0.000 & 0.010 & 0.125 & 0.073 \\
Basket peg & 0.000 & 0.022 & 0.914 & 0.014 & 0.000 & 0.043 & 0.007 \\
Horizontal band & 0.021 & 0.000 & 0.021 & 0.792 & 0.021 & 0.125 & 0.021 \\
Craw ling peg/band & 0.000 & 0.016 & 0.000 & 0.031 & 0.875 & 0.063 & 0.016 \\
Managed float & 0.004 & 0.014 & 0.002 & 0.004 & 0.004 & 0.932 & 0.041 \\
Independent float & 0.008 & 0.000 & 0.003 & 0.000 & 0.005 & 0.059 & 0.925 \\
Steady-state distribution & 0.153 & 0.031 & 0.025 & 0.014 & 0.030 & 0.424 & 0.323 \\
Regime distribution in 2011 & 0.137 & 0.039 & 0.039 & 0.000 & 0.020 & 0.490 & 0.275 \\
\hline
\end{tabular}


Table A3. Transition Probabilities Matrix for EMs: RR's De Facto Classification, 1980-2010

(c) Aggregate classification

\begin{tabular}{lcrr}
\hline & Fixed & Intermediate & \multicolumn{1}{l}{ Float } \\
\cline { 2 - 4 } Fixed & 0.95 & 0.05 & 0.00 \\
Intermediate & 0.01 & 0.99 & 0.00 \\
Float & 0.04 & 0.07 & 0.89 \\
\hline Steady-state regime & 0.17 & 0.82 & 0.01 \\
Regime distribution in 2010 & 0.19 & 0.79 & 0.02 \\
\hline
\end{tabular}

Note: Fixed includes no separate legal tender, pre-announced peg and currency board; Intermediate includes pre-announced horizontal band $\leq+/-2 \%$, de facto peg, preannounced crawling peg, pre-announced crawling $\leq+/-2 \%$, de facto crawling peg, de facto crawling band $\leq+/-2 \%$; pre-announced crawling band $\geq+/-5 \%$, de facto crawling band $\leq+/-5 \%$, moving band $\leq+/-2 \%$, and managed float; Float includes free float. The categories of freely falling and dual market where parallel data is missing are excluded from the computations.

\section{(d) Fine classification}

\begin{tabular}{|c|c|c|c|c|c|c|c|c|c|c|c|}
\hline & $\begin{array}{c}\text { No separate } \\
\text { legal tender/ Pre } \\
\text { announced peg/ } \\
\text { Currency board }\end{array}$ & $\begin{array}{c}\text { De facto } \\
\text { peg }\end{array}$ & $\begin{array}{c}\text { Pre } \\
\text { announced } \\
\text { craw ling peg }\end{array}$ & $\begin{array}{c}\text { Pre } \\
\text { announced } \\
\text { craw ling } \\
\text { band } \leq+/-2 \%\end{array}$ & $\begin{array}{c}\text { De facto } \\
\text { craw ling } \\
\text { peg }\end{array}$ & $\begin{array}{c}\text { De facto } \\
\text { craw ling } \\
\text { band } \leq \\
+/-2 \% \\
\end{array}$ & $\begin{array}{c}\text { Pre } \\
\text { announced } \\
\text { craw ling } \\
\text { band } \geq+/-2 \%\end{array}$ & $\begin{array}{c}\text { De facto } \\
\text { craw ling } \\
\text { band } \leq \\
+/-5 \% \\
\end{array}$ & $\begin{array}{l}\text { Moving } \\
\text { band } \leq \\
+/-2 \%\end{array}$ & $\begin{array}{c}\text { Managed } \\
\text { floating }\end{array}$ & $\begin{array}{l}\text { Free } \\
\text { float }\end{array}$ \\
\hline $\begin{array}{l}\text { No separate legal tender/ Pre } \\
\text { announced peg/ Currency board }\end{array}$ & 0.953 & 0.006 & 0.000 & 0.000 & 0.012 & 0.012 & 0.000 & 0.012 & 0.000 & 0.006 & 0.000 \\
\hline De facto peg & 0.009 & 0.889 & 0.000 & 0.000 & 0.028 & 0.009 & 0.009 & 0.028 & 0.009 & 0.019 & 0.000 \\
\hline Pre announced craw ling peg & 0.000 & 0.200 & 0.800 & 0.000 & 0.000 & 0.000 & 0.000 & 0.000 & 0.000 & 0.000 & 0.000 \\
\hline Pre announced craw ling band $\leq+/-2 \%$ & 0.053 & 0.000 & 0.000 & 0.842 & 0.053 & 0.000 & 0.053 & 0.000 & 0.000 & 0.000 & 0.000 \\
\hline De facto craw ling peg & 0.013 & 0.019 & 0.000 & 0.013 & 0.906 & 0.050 & 0.000 & 0.000 & 0.000 & 0.000 & 0.000 \\
\hline De facto craw ling band $\leq+/-2 \%$ & 0.011 & 0.011 & 0.004 & 0.000 & 0.040 & 0.879 & 0.004 & 0.029 & 0.004 & 0.015 & 0.004 \\
\hline Pre announced craw ling band $\geq+/-2 \%$ & 0.000 & 0.000 & 0.000 & 0.000 & 0.125 & 0.125 & 0.500 & 0.250 & 0.000 & 0.000 & 0.000 \\
\hline De facto craw ling band $\leq+/-5 \%$ & 0.000 & 0.024 & 0.000 & 0.000 & 0.006 & 0.047 & 0.012 & 0.882 & 0.000 & 0.030 & 0.000 \\
\hline Moving band $\leq+/-2 \%$ & 0.059 & 0.059 & 0.000 & 0.000 & 0.000 & 0.000 & 0.000 & 0.000 & 0.882 & 0.000 & 0.000 \\
\hline Managed floating & 0.000 & 0.008 & 0.000 & 0.000 & 0.008 & 0.033 & 0.000 & 0.025 & 0.008 & 0.917 & 0.000 \\
\hline Freely floating & 0.037 & 0.000 & 0.000 & 0.000 & 0.000 & 0.000 & 0.000 & 0.074 & 0.000 & 0.000 & 0.889 \\
\hline Steady-state distribution & 0.173 & 0.119 & 0.004 & 0.014 & 0.182 & 0.200 & 0.009 & 0.143 & 0.024 & 0.125 & 0.007 \\
\hline Regime distribution in 2010 & 0.192 & 0.096 & 0.000 & 0.000 & 0.173 & 0.135 & 0.000 & 0.231 & 0.019 & 0.135 & 0.019 \\
\hline
\end{tabular}

Note: The categories of freely falling and dual market where parallel data is missing are excluded from the computations. 


\section{APPEndix B: DAta AND AdDitional Estimation Results}

Table B1. Data Description and Sources

\begin{tabular}{|c|c|c|}
\hline Variable & Description & Data sources \\
\hline \multicolumn{3}{|c|}{ IMF's de facto and de jure exchange rate regime classification } \\
\hline Fine & $\begin{array}{l}\text { 1: Hard peg (No separate legal tender/currency board); } 2 \text { : } \\
\text { Peg to single currency; } 3 \text { : B asket currency peg; } 4 \text { : } \\
\text { Horizontal band; } 5 \text { : Crawling peg/band; 6: M anaged float; } 7 \text { : } \\
\text { Independent float }\end{array}$ & $\begin{array}{l}\text { Anderson (2008) }{ }^{1} \text {; IM F's AREAER } \\
\text { (various issues) }\end{array}$ \\
\hline Aggregate & Fixed: 1, Intermediate: 2-6, Float: 7 & \\
\hline \multicolumn{3}{|c|}{ Reinhart and Rogoff's de facto exchange rate regime classification } \\
\hline Fine & $\begin{array}{l}\text { 1: No separate legal tender; } 2 \text { : Pre anno unced peg/currency } \\
\text { board; } 3 \text { : Pre anno unced band } \leq+/-2 \% ; 4 \text { : De facto peg; } 5 \text { : } \\
\text { Pre anno unced crawling peg; } 6 \text { : Pre anno unced crawling } \\
\text { band } \leq+/-2 \% ; 7 \text { : De facto crawling peg; } 8 \text { : De facto crawling } \\
\text { band } \leq+/-2 \% ; 9 \text { : Pre announced crawling band } \geq+/-2 \% ; 10 \text { : } \\
\text { De facto crawling band } \leq+/-5 \% ; 11 \text { : M oving band } \leq+/-2 \% ; 12 \text { : } \\
\text { M anaged float; 13: Freely floating; } 14 \text { : Freely falling; } 15 \text { : Dual } \\
\text { market (missing parallel data) }\end{array}$ & $\begin{array}{l}\text { Ilzetzki at al. (2010). }{ }^{2} \text { A vailable online at } \\
\text { http://personal.Ise.ac.uk/ilzetzki/data.htm }\end{array}$ \\
\hline Aggregate & Fixed: 12 , Intermediate: $3-12$, Float: 13 & \\
\hline \multicolumn{3}{|l|}{ Crisis variables } \\
\hline 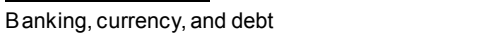 & Binary variable (1equals crisis; 0 otherwise) & Laeven and Valencia $(2012)^{3}$ \\
\hline Growth crisis & $\begin{array}{l}\text { Binary variable ( } 1 \text { equals crisis defined as botto } m \text { th } \\
\text { percentile of the growth decline distribution calculated as } \\
\text { the difference between real GDP growth in } t \text { and the } \\
\text { average growth in } t-1, t-2 \text { and } t-3 ; 0 \text { otherwise) }\end{array}$ & Authors' estimates \\
\hline \multicolumn{3}{|l|}{ Macroeconomic variables } \\
\hline Inflation & $\begin{array}{l}\text { Annual change in average consumer price index } \\
\text { (transformed as } x /(100+x) \text { if } x \geq 0 \text {; and } x /(100-x) \text { if } x<0 \text {; In pct.) }\end{array}$ & IM F's WEO database \\
\hline Current account balance to GDP & In percent & IMF's WEO database \\
\hline Net financial flows to GDP & Excluding reserves (In percent) & IFS database \\
\hline External debt to GDP & Foreign debt liabilities to GDP (In percent) & $\begin{array}{l}\text { Updated and extended version of Lane } \\
\text { and M ilesi-Ferreti }(2007)^{4}\end{array}$ \\
\hline Fiscal deficit to GDP & General govt. net lending/bo rrowing (In percent) & IM F's WEO database \\
\hline Real effective exchange rate (REER) deviation & $\begin{array}{l}\text { Deviation of the REER from trend (obtained from HP } \\
\text { filter; smoothing parameter }=100 \text { ) }\end{array}$ & $\begin{array}{l}\text { Authors' estimates based on REER data } \\
\text { obtained from INS }\end{array}$ \\
\hline Real GDP growth rate & Transformed as $x /(100+x)$ if $x \geq 0$; and $x /(100-x)$ if $x<0$ (In pct.) & IM F's WEO database \\
\hline Real GDP per capita & In logs & World Bank's WDI \\
\hline Reserves to GDP & In percent & IFS database \\
\hline Terms of trade change & Change in terms of trade index (In percent) & IMF's WEO database \\
\hline Trade opennes & Sum of exports and imports to GDP (In percent) & IM F's WEO database \\
\hline Trading partner growth & $\begin{array}{l}\text { Export-share weighted average of real GDP growth of top } \\
3 \text { advanced trading partners (In percent) }\end{array}$ & $\begin{array}{l}\text { Authors' estimates based on IM F's } \\
\text { WEO and DOTS databases }\end{array}$ \\
\hline \multicolumn{3}{|l|}{ Financial variables } \\
\hline Bank loans in foreign currency to to tal bank loans & In percent & IMF Staff Reports and staff estimates. \\
\hline Bank foreign liabilities to GDP & In percent & IFS database \\
\hline Private sector credit to GDP & In percent & IFS database \\
\hline Domestic credit boom & $\begin{array}{l}\text { 3-year change in private sector credit to GDP (In } \\
\text { percentage points) }\end{array}$ & Authors' estimates \\
\hline Initial domestic credit to GDP & $\begin{array}{l}\text { 3-year avg. of private credit to GDP at the start of the } \\
\text { boom (In pct.) }\end{array}$ & Authors' estimates \\
\hline \multicolumn{3}{|l|}{ Other variables } \\
\hline Capital account openness index & Index (higher values indicating greater openness) & Extended version of Chinn and Ito $(2006)^{5}$ \\
\hline Capital controls on inflows index & Index (higher values indicating lower openness) & Schindler $(2009)^{6}$ \\
\hline Institutional quality & $\begin{array}{l}\text { Index (average of } 12 \text { political risk components with higher } \\
\text { values indicating better institutional quality) }\end{array}$ & $\begin{array}{l}\text { ICRG. Available online at: } \\
\text { http://www.prsgroup.com/ICRG.aspx }\end{array}$ \\
\hline Reserve requirements & Index (higher values indicating lower requirements) & Detragiache et al. $(2008)^{7}$ \\
\hline Contagion & Proportion of other EM Es in a (banking or currency) crisis & $\begin{array}{l}\text { Authors' estimated based on Laeven } \\
\text { and Valencia (2012) }\end{array}$ \\
\hline Foreign currency related prudential measures & B inary variable ( $1=$ restriction in place; 0 otherwise) & IMF's AREAER (various issues) \\
\hline Fiscal rules & Binary variable ( $1=$ rule exists; 0 otherwise) & IMF's FAD Fiscal Rules database \\
\hline
\end{tabular}

1/ Anderson, H., 2008, "Exchange Policies before Widespread Floating (1945-89)," mimeo, International Monetary Fund.

2/ Izetzki, E., C. Reinhart and K. Rogoff, 2010, "Exchange Rate Arrangements Entering the 21st Century: Which Anchor Will Hold?" mimeo, UMD.

3/ Laeven, L., and F. Valencia, 2012, "Systemic Banking Crises Database: An Update," IMF Working Paper WP/12/163.

4/ Lane, P., and G.M. Milesi-Ferretti, 2007, "The External Wealth of Nations Mark II: Revised and Extended Estimates of Foreign Assets and Liabilities, 1970-2004," Journal of International Economics, 73(2), pp. 223-250.

5/ Chinn, M., and H. Ito, 2006, "What Matters for Financial Development? Capital Controls, Institutions, and Interactions," Journal of Development Economics, 81(1): 163-192. 6/ Schindler, M., 2009, "Measuring Financial Integration: A New Dataset," IMF Staff Papers, 56(1), pp. 222-238.

7/ Detragiache, E., A. Abiad, and T. Tressel, 2008, "A New Database of Financial Reforms," IMF Working Papers 08/266. 
Table B2. Robustness Analysis: IMF's De Facto Regime Classification, 1980-2011

\begin{tabular}{|c|c|c|c|c|c|c|c|c|c|c|c|c|c|c|}
\hline & \multicolumn{2}{|c|}{ All crisis } & \multicolumn{4}{|c|}{ Banking cris is } & \multicolumn{4}{|c|}{ Currency crisis } & \multicolumn{2}{|c|}{ Debt crisis } & \multicolumn{2}{|c|}{ Growth crisis } \\
\hline & Baseline $^{a}$ & $\begin{array}{c}\text { With } \\
\text { controls }\end{array}$ & $\begin{array}{c}\text { Addl. } \\
\text { Controls }^{\mathrm{c}}\end{array}$ & $\begin{array}{l}\text { Bank } \\
\text { NFA }^{d}\end{array}$ & $\begin{array}{c}\text { Bank } \\
\text { contagion }\end{array}$ & $\begin{array}{c}\text { Year- } \\
\text { effects }^{f}\end{array}$ & $\begin{array}{c}\text { Addl. } \\
\text { Controls }\end{array}$ & $\begin{array}{c}\text { Hyper } \\
\text { inflationg }\end{array}$ & $\begin{array}{c}\text { Banking } \\
\text { crisis }^{h}\end{array}$ & $\begin{array}{c}\text { Year- } \\
\text { effects }^{f}\end{array}$ & $\begin{array}{c}\text { Addl. } \\
\text { Controls }\end{array}$ & $\begin{array}{c}\text { Year- } \\
\text { effects }^{f}\end{array}$ & $\begin{array}{c}\text { Addl. } \\
\text { Controls }\end{array}$ & $\begin{array}{c}\text { Year- } \\
\text { effects }^{f}\end{array}$ \\
\hline & (1) & (2) & (3) & $(4)$ & (5) & (6) & (7) & (8) & (9) & $(10)$ & $(11)$ & $(12)$ & (13) & $(14)$ \\
\hline \multirow[t]{2}{*}{ Hard peg } & $0.506^{*}$ & 0.427 & 0.521 & 0.243 & 0.253 & 0.471 & -0.602 & $-0.697^{*}$ & $-0.682^{* *}$ & $-0.711^{* *}$ & 0.030 & 0.321 & 0.256 & $0.529^{* *}$ \\
\hline & $(0.270)$ & $(0.287)$ & $(0.584)$ & $(0.592)$ & $(0.602)$ & $(0.626)$ & $(0.369)$ & $(0.371)$ & $(0.336)$ & $(0.346)$ & $(0.260)$ & $(0.262)$ & $(0.267)$ & $(0.262)$ \\
\hline \multirow[t]{2}{*}{ Peg to single currency } & $0.682^{* * *}$ & $0.750^{* * *}$ & 0.458 & 0.491 & 0.489 & 0.522 & 0.096 & 0.173 & 0.282 & 0.254 & 0.023 & 0.223 & $0.854^{* * *}$ & $0.739^{* \star *}$ \\
\hline & $(0.252)$ & $(0.283)$ & $(0.479)$ & $(0.472)$ & $(0.474)$ & $(0.608)$ & $(0.334)$ & $(0.330)$ & $(0.331)$ & $(0.344)$ & $(0.399)$ & $(0.389)$ & $(0.256)$ & $(0.270)$ \\
\hline \multirow[t]{2}{*}{ Basket peg } & 0.198 & 0.105 & 0.346 & 0.488 & 0.481 & 0.516 & -0.433 & -0.326 & -0.345 & -0.229 & 0.043 & 0.335 & $0.920^{\star *}$ & $0.794^{*}$ \\
\hline & $(0.267)$ & $(0.326)$ & $(0.494)$ & $(0.518)$ & $(0.533)$ & $(0.644)$ & $(0.457)$ & $(0.452)$ & $(0.436)$ & $(0.476)$ & $(0.440)$ & $(0.394)$ & $(0.436)$ & $(0.416)$ \\
\hline \multirow[t]{2}{*}{ Horizontal band } & $0.715^{\star \star}$ & $0.607^{*}$ & $1.219^{\star \star \star}$ & $1.205^{\star \star *}$ & $1.179^{\star \star *}$ & $1.414^{\star *}$ & 0.198 & 0.212 & 0.290 & 0.149 & 0.467 & 0.479 & 0.113 & 0.055 \\
\hline & $(0.312)$ & $(0.367)$ & $(0.455)$ & $(0.446)$ & $(0.448)$ & $(0.565)$ & $(0.414)$ & $(0.425)$ & $(0.437)$ & $(0.478)$ & $(0.526)$ & $(0.488)$ & $(0.415)$ & $(0.554)$ \\
\hline \multirow[t]{2}{*}{ Craw ling peg/band } & $0.616^{\star *}$ & $0.460^{*}$ & $0.770^{*}$ & $0.736^{*}$ & $0.742^{*}$ & $0.868^{*}$ & 0.121 & 0.193 & 0.362 & 0.226 & -0.021 & 0.218 & 0.063 & -0.003 \\
\hline & $(0.263)$ & $(0.262)$ & $(0.417)$ & $(0.417)$ & $(0.418)$ & $(0.523)$ & $(0.309)$ & $(0.302)$ & $(0.285)$ & $(0.293)$ & $(0.365)$ & $(0.398)$ & $(0.262)$ & $(0.292)$ \\
\hline \multirow[t]{2}{*}{ Managed float } & 0.329 & 0.399 & 0.479 & 0.447 & 0.464 & 0.531 & 0.224 & 0.241 & 0.362 & 0.268 & 0.161 & 0.239 & 0.021 & -0.181 \\
\hline & $(0.245)$ & $(0.277)$ & $(0.462)$ & $(0.470)$ & $(0.471)$ & $(0.597)$ & $(0.264)$ & $(0.271)$ & $(0.272)$ & $(0.269)$ & $(0.344)$ & $(0.328)$ & $(0.263)$ & $(0.306)$ \\
\hline Region-fixed effects & Yes & Yes & Yes & Yes & Yes & Yes & Yes & Yes & Yes & Yes & Yes & Yes & Yes & Yes \\
\hline Observations & 1,012 & 1,012 & 1,031 & 1,063 & 1,063 & 1,063 & 1,192 & 1,258 & 1,258 & 1,258 & 1,135 & 1,193 & 1,103 & 1,220 \\
\hline R-squared & 0.048 & 0.21 & 0.192 & 0.160 & 0.163 & 0.342 & 0.235 & 0.228 & 0.262 & 0.270 & 0.236 & 0.276 & 0.262 & 0.371 \\
\hline
\end{tabular}

Note: Dependent variable is a binary variable with one indicating a: crisis (banking, currency, debt or growth) in cols. [1]-[2]; banking crisis in cols. [3]-6]; currency crisis in cols. [7]-[9]; debt crisis in cols. [10]-[11]; and growth crisis in cols. [12]-[13]. All specifications are estimated as a probit model, with all regressors lagged one perio d, and constant and region-specific effects included. Clustered standard errors at the country

level reported in parentheses. ${ }^{* \star *}, * *$ and ${ }^{*}$ indicate statistical significance at the 1,5 , and 10 percent levels, respectively.

a Control variable includes (log) real GDP per capita.

${ }^{\mathrm{b}}$ Control variables include (log) real GDP per capita, real GDP growth, inflation, net capital flows/GDP, bank foreign liabilities to GDP, do mestic credit expansion, real exchange rate overvaluation, reserves/GDP,

current account balance/GDP, external debt/GDP, and fiscal balance/GDP.

${ }^{\circ}$ Control variables include those in Tables 10 and 11, and trade openness/GDP, institutional quality, and capital account openness index.

d Bank foreign liabilities to GDP ratio replaced with bank's net foreign assets to GDP ratio as a control variable.

${ }^{\mathrm{B}} \mathrm{B}$ ank contagion measure (defined as the proportion of other EM Es in the sample experiencing a banking crisis) included in the regression with other control variables

f Year effects included in the specification with other controls variables.

${ }^{9} \mathrm{~A}$ binary variable for hyper inflation (equal to one for inflation rates higher than 40 percent) included in the estimation to control for high inflation cases.

${ }^{\mathrm{h}} \mathrm{A}$ binary variable for banking crisis (lagged) included in the estimation with other control variables. 
Table B3: Economic Characteristics and Exchange Rate Regime Switches: IMF's De Facto Classification, 1980-2011

\begin{tabular}{lcc}
\hline & $\begin{array}{c}\text { Switch to less } \\
\text { flexible regimes }\end{array}$ & $\begin{array}{c}\text { Switch to more } \\
\text { flexible regimes }\end{array}$ \\
\cline { 2 - 2 } Net capital flow s/GDP (in pct.) & 2.2 & 3.3 \\
FX loans/total loans (in pct.) & 37.5 & 38.9 \\
Domestic credit change (in ppt.) & 2.6 & 1.7 \\
Current acct. balance/GDP (in pct.) & -3.9 & -4.4 \\
REER overvaluation (in pct.) & -2.2 & $2.0^{* *}$ \\
Real GDP grow th (in pct.) & 2.0 & 1.8 \\
Institutional quality index & 0.6 & 0.6 \\
Capital account openness index & -0.1 & -0.4 \\
Trade openness (in pct.) & 73.1 & 73.7 \\
\cline { 1 - 2 }
\end{tabular}

Note: Statistics reflect average in year before the exchange rate regime switch. ${ }^{*}$ indicate that the difference in means between tho se switching toward mo re flexible regimes and tho se toward less flexible regimes is statistically significant at the 5 percent level.

Figure B1. NEER Volatility and Exchange Rate Regimes (In percent)

(a) IMF's De Facto Classification

(b) RR's De Facto Classification

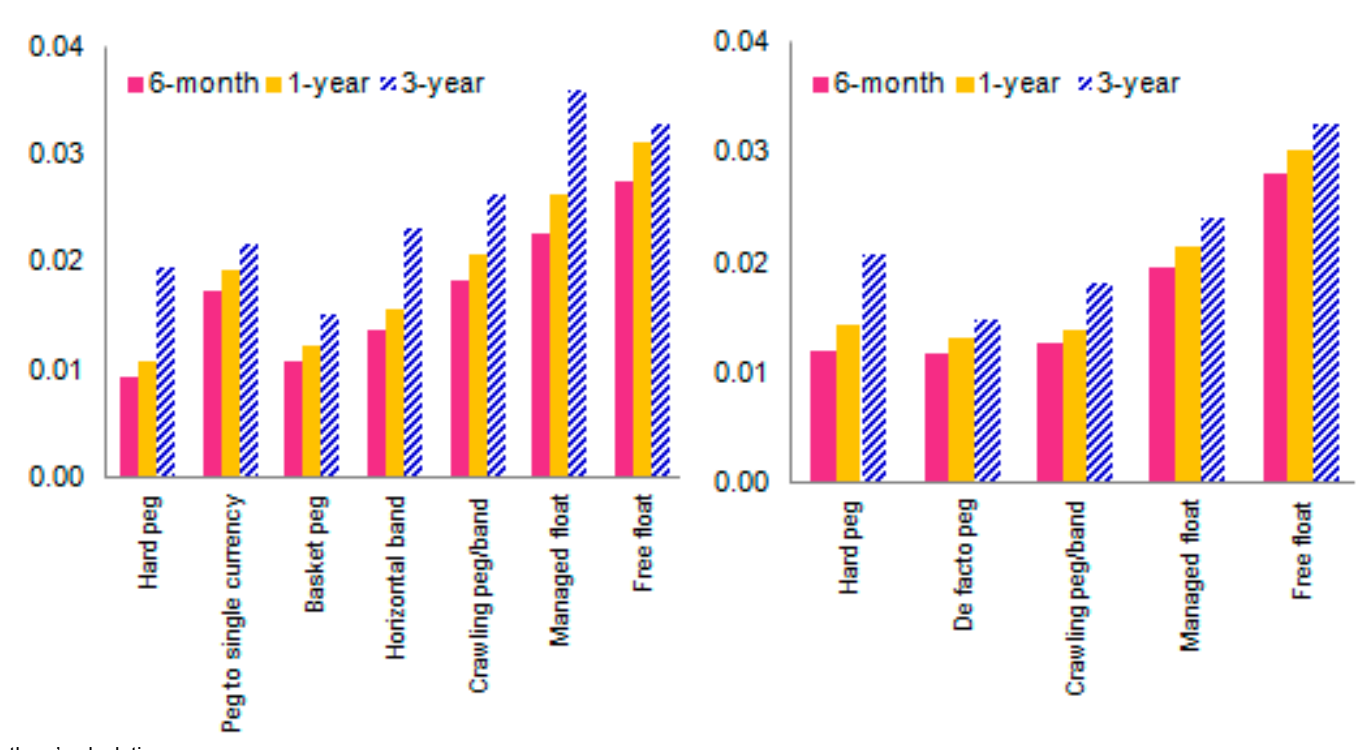

Source: Authors' calculations

Note: Volatility is defined as average (for the corresponding year) of rolling standard deviation of monthly percentage change in nominal effective exchange rate (NEER) over horizon $n$ (where $n=6,12$ and 36 months). 
Table B4. Crisis Susceptibility: IMF's De Jure Classification, 1980-2011

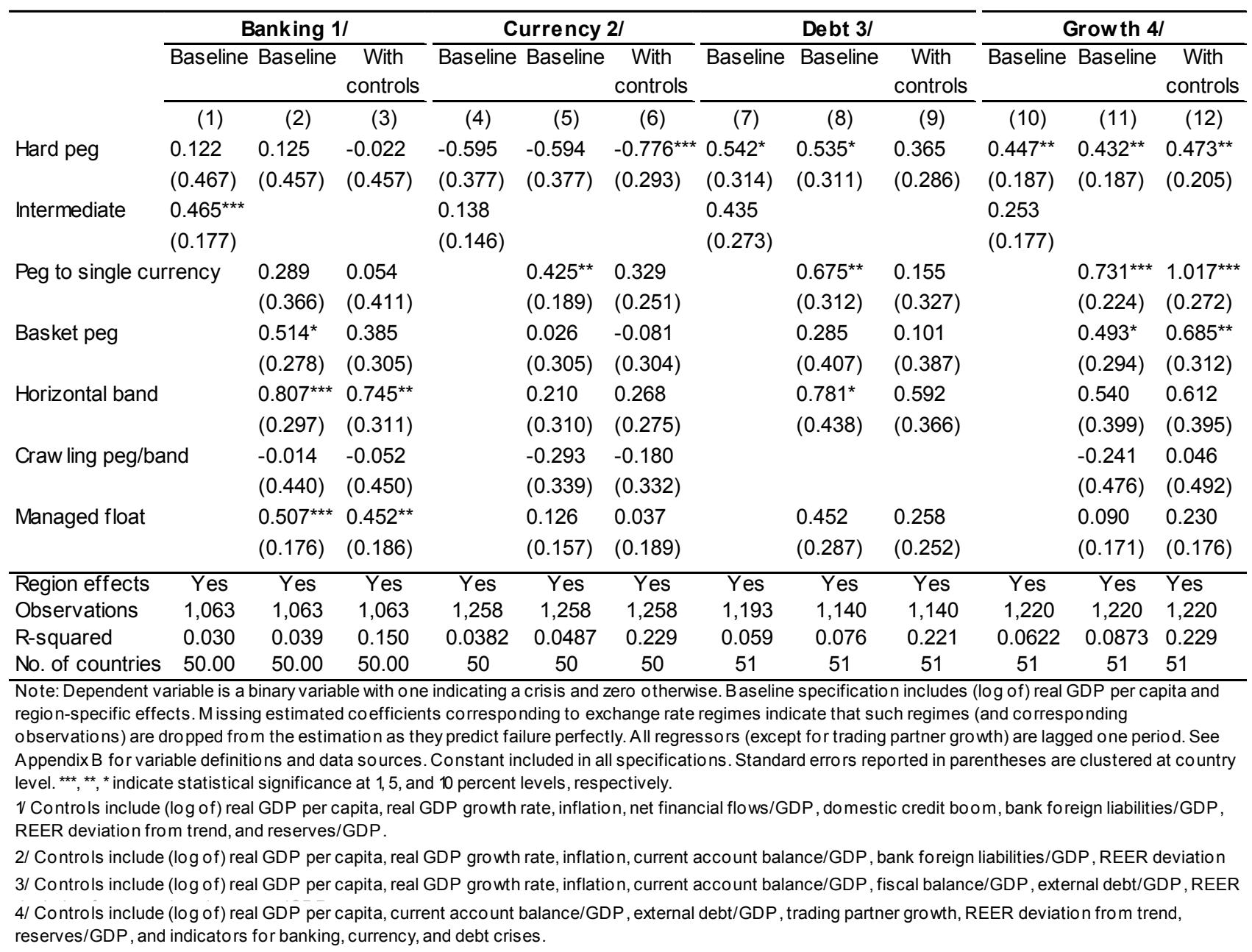


Table B5. Crisis Susceptibility: RR's De Facto Classification, 1980-2010

\begin{tabular}{|c|c|c|c|c|c|c|c|c|c|c|c|c|}
\hline & \multicolumn{3}{|c|}{ Banking 1/ } & \multicolumn{3}{|c|}{ Currency 2/ } & \multicolumn{3}{|c|}{ Debt 3/ } & \multicolumn{3}{|c|}{$\begin{array}{c}\text { Growth 4/ } \\
\end{array}$} \\
\hline & Baseline & Baseline & $\begin{array}{c}\text { With } \\
\text { controls }\end{array}$ & Baseline & Baseline & $\begin{array}{c}\text { With } \\
\text { controls }\end{array}$ & Baseline & Baseline & $\begin{array}{c}\text { With } \\
\text { controls }\end{array}$ & Baseline & Baseline & $\begin{array}{c}\text { With } \\
\text { controls }\end{array}$ \\
\hline & (1) & (2) & $(3)$ & (4) & (5) & (6) & (7) & (8) & (9) & (10) & (11) & $(12)$ \\
\hline Hard peg & $\begin{array}{l}3.397^{\star * *} \\
(0.313)\end{array}$ & $\begin{array}{l}3.365^{\star * *} \\
(0.312)\end{array}$ & $\begin{array}{l}3.771^{* \star *} \\
(0.391)\end{array}$ & $\begin{array}{l}0.002 \\
(0.536)\end{array}$ & $\begin{array}{l}-0.002 \\
(0.543)\end{array}$ & $\begin{array}{l}-0.408 \\
(0.696)\end{array}$ & $\begin{array}{l}3.756^{\star * *} \\
(0.249)\end{array}$ & $\begin{array}{l}3.744^{* * *} \\
(0.249)\end{array}$ & $\begin{array}{l}3.961^{\star * *} \\
(0.428)\end{array}$ & $\begin{array}{l}0.480 \\
(0.471)\end{array}$ & $\begin{array}{l}0.377^{\star *} \\
(0.171)\end{array}$ & $\begin{array}{l}0.409^{\star *} \\
(0.161)\end{array}$ \\
\hline Intermediate & $\begin{array}{l}3.548^{* * *} \\
(0.155)\end{array}$ & & & $\begin{array}{l}-0.205 \\
(0.536)\end{array}$ & & & $\begin{array}{l}3.247^{\star \star *} \\
(0.196)\end{array}$ & & & $\begin{array}{l}0.103 \\
(0.473)\end{array}$ & & \\
\hline De facto peg & & $\begin{array}{l}3.761^{* * *} \\
(0.242)\end{array}$ & $\begin{array}{l}4.249^{* * *} \\
(0.294)\end{array}$ & & $\begin{array}{l}-0.071 \\
(0.562)\end{array}$ & $\begin{array}{l}0.077 \\
(0.710)\end{array}$ & & & & & & \\
\hline Craw ling peg/bar & & $\begin{array}{l}3.574^{* * *} \\
(0.156)\end{array}$ & $\begin{array}{l}4.079^{* * *} \\
(0.194)\end{array}$ & & $\begin{array}{l}-0.279 \\
(0.534)\end{array}$ & $\begin{array}{l}-0.551 \\
(0.655)\end{array}$ & & $\begin{array}{l}3.247^{* * *} \\
(0.212)\end{array}$ & $\begin{array}{l}3.558^{\star * *} \\
(0.299)\end{array}$ & & & \\
\hline Managed float & & $\begin{array}{l}3.381^{* * *} \\
(0.240)\end{array}$ & $\begin{array}{l}3.896^{* * *} \\
(0.246)\end{array}$ & & $\begin{array}{l}-0.168 \\
(0.582)\end{array}$ & $\begin{array}{l}-0.286 \\
(0.651)\end{array}$ & & $\begin{array}{l}3.327^{\star \star *} \\
(0.253)\end{array}$ & $\begin{array}{l}3.647^{* \star *} \\
(0.369)\end{array}$ & & $\begin{array}{l}-0.103 \\
(0.473)\end{array}$ & $\begin{array}{l}0.094 \\
(0.555)\end{array}$ \\
\hline Region effects & Yes & Yes & Yes & Yes & Yes & Yes & Yes & Yes & Yes & Yes & Yes & Yes \\
\hline Observations & 922 & 922 & 922 & 1,052 & 1,052 & 1,052 & 1,020 & 907 & 907 & 1,038 & 1,038 & 1,038 \\
\hline R-squared & 0.017 & 0.025 & 0.138 & 0.0270 & 0.0294 & 0.372 & 0.035 & 0.031 & 0.278 & 0.0750 & 0.0750 & 0.265 \\
\hline No. of countries & 49 & 49 & 49 & 49 & 49 & 49 & 50 & 50 & 50 & 50 & 50 & 50 \\
\hline
\end{tabular}

Note: Dependent variable is a binary variable with one indicating a crisis and zero otherwise. Baseline specification includes (log of) real GDP per capita and region-specific effects. RR's fine classification is grouped as follows: Fixed=12; Intermediate=3-12; $\mathrm{Float}=13$ (Hard peg=12; Horizontal band=3; De facto peg=4; Crawling peg/band $=5-9 ; \mathrm{M}$ anaged flo at $=10-12 ; \mathrm{Float}=13$ ). $\mathrm{M}$ issing estimated co efficients co rresponding to exchange rate regimes indicate that such regimes (and co rresponding observations) are dropped from the estimation as they predict failure perfectly. All regressors (except for trading partner gro wth) are lagged one period. See Appendix B for variable definitions and data sources. Constant included in all specifications. Standard errors reported in parentheses are clustered at country level. ${ }^{* * *},{ }^{* *},{ }^{*}$ indicate statistical significance at 1,5 , and 10 percent levels, respectively.

1 Controls include (log of) real GDP per capita, real GDP growth rate, inflation, net financial flows/GDP, domestic credit boom, bank foreign liabilities/GDP, REER deviation from trend, and reserves/GDP.

2/ Controls include (log of) real GDP per capita, real GDP growth rate, inflation, current account balance/GDP, bank fo reign liabilities/GDP, REER deviation from trend, and reserves/GDP.

3/ Controls include (log of) real GDP per capita, real GDP growth rate, inflation, current acco unt balance/GDP, fiscal balance/GDP, external debt/GDP, REER deviation from trend, and reserves/GDP.

4/ Controls include (log of) real GDP per capita, current account balance/GDP, external debt/GDP, trading partner growth, REER deviation from trend, reserves/GDP, and indicators for banking, currency, and debt crises. 